\title{
Araucaria de Chile: uma revista de resistência cultural
}

Eça Pereira da Silva ${ }^{1}$

Resumo: Este artigo é fruto da pesquisa de mestrado que investigou as ideias culturais e políticas difundidas pela revista Araucaria de Chile, publicada inicialmente em 1978 por um grupo de intelectuais chilenos exilados, ligados ao Partido Comunista Chileno (PCCh), e encerrada em 1990, após o resultado do plebiscito que pôs fim à ditadura. Tratava-se de uma revista cultural com claro posicionamento político contra o regime pinochetista e demais ditaduras que assolaram o continente sul-americano entre os anos 1960 e 1980. Aqui será enfocado como a Araucaria divulgou e analisou as diversas manifestações artísticas de chilenos no exílio, e também, quando possível, dentro do país.

Palavras-chave: revista, cultura, Chile.

Abstract: This article is the result of the mastership`s research that investigated the cultural and politics ideas defaund by the magazine Araucaria de Chile, first published in 1978 by a intelectuals exile's group, that were close to the Chilean Comunist Party (PCCh), and ended in 1990, after the result of the plebiscit that finished the dictatorship. That was a cultural magazine with a clear politic position against Pinochet's government and others dictatorships in South America between 1960 and 1980. Ill show here how the Araucaria magazine published and analyzed all the chileans exile's artistics manifestations, and when were possible, inside Chile too.

Keywords: magazine, culture, Chile.

\section{O surgimento da publicação}

A proposta de lançar uma revista cultural, segundo Luis Corvalán (1997, p. 248) então secretário geral do Partido Comunista Chileno (PCCh), surgiu durante a primeira reunião da direção do PCCh depois do golpe de Estado que derrubou governo de

1 Mestre em História Social pela USP, cuja pesquisa de mestrado teve financiamento da FAPESP. Atualmente é doutoranda na mesma instituição e desenvolve a pesquisa que consiste numa comparação entre instituições de formação intelectual para militares brasileiros e peruanos. E-mail: ecapereira@usp.br

Revista Eletrônica da ANPHLAC, n.10, p. 83-125, jan./jun. 2011. 
Salvador Allende em 1973, realizada em agosto de 1977 na cidade de Moscou. Já conforme Carlos Orellana (1994, p. 14), secretário de redação da Araucaria, a iniciativa teria partido da direção do Partido Comunista Chileno no exterior, coordenada por Volodia Teitelboim que reuniu um grupo de intelectuais em maio de 1977 em Roma com o objetivo de fundar a revista (MILLAS, 1996, p.173; CORVALÁN, 1997, p. 214). Apesar da não coincidência das datas, ambos atribuem a realização da Araucaria a Volodia Teitelboim, que se definia como um homem "casado com a política e amante da literatura", cuja trajetória pública passava, então, dos 40 anos.

A reunião que fundou a revista ocorreu mesmo em Roma, pois parecia o melhor local para congregar os exilados residentes em diversos países da Europa, e também, segundo Volodia, porque ali se fazia um importante trabalho de solidariedade aos chilenos (TEITELBOIM, 2007). Para a escolha da cidade pesou ainda o fato de que ali se editava, desde setembro de 1974, a importante revista de debates políticos e teóricos Chile-América dirigida pelo destacado intelectual do Partido Socialista Antonio Vieira Gallo, e outros que representavam a ala "esquerda" da Democracia Cristã (DC), como Bernardo Leighton, Esteban Tomic, Julio Silva e Fernando Murillo (ARRATE; ROJAS, 2003, p. 411). ${ }^{2}$

O editorial de lançamento da Araucaria esclareceu que o título escolhido para a revista era uma referência a três ícones da identidade chilena: a árvore tradicional, o poema épico La Araucana e os indígenas araucanos. Em relação aos exilados, a metáfora da árvore servia para evidenciar a relação com as raízes, ou seja, a terra natal com a qual tentavam manter os vínculos apesar da distância que o exílio impunha. Embora não desejassem enveredar pelo caminho do folclorismo, a alusão aos indígenas araucanos sugere a equiparação da resistência destes aos projetos civilizatórios, que duraram três séculos, à resistência à ditadura de Pinochet; além disso, a araucária simboliza a esperança no país mais ao sul do globo. Quanto ao poema La Araucana de autoria de Alonso de Ercilla, escrito no século XVI, cabe esclarecer que ele consiste numa grande ode à união dos povos ibéricos e indígenas. ${ }^{3}$ Assim, a referência ao poema

2 A revista Chile-América, editada em Roma por um grupo de intelectuais do Partido Socialista foi uma das mais importantes revistas de debate político editadas durante o exílio; nos EUA, um grupo da Izquierda Cristiana publicou El Barco de Papel; no Canadá a comunidade de chilenos publicou os jornais Unidad e El Correo e a revista Aqui; em Madrid editaram o Boletín Documentacion Teatral. Ainda, nos EUA, o escritor Fernando Alegria dirigiu a revista Literatura Chilena no Exílio. Esses são alguns exemplos na área dos periódicos da imensa produção cultural de chilenos no exílio. (REBOLLEDO, 2006, p. 106).

3 Cabe lembrar que, embora esse poema date do século XVI, os araucanos só foram derrotados no século XIX.

Revista Eletrônica da ANPHLAC, n.10, p. 83-125, jan./jun. 2011. http://revista.anphlac.org.br/index.php/revista 
de Ercilla se deve ao signo do "reencontro" proposto pelo poeta, e o desejo dos produtores da revista de estabelecer o diálogo entre os chilenos que estavam no Velho e os que haviam ficado no Novo Mundo (Editorial, Araucária, n. 1, 1978, p. 6).

O mesmo editorial de Araucaria expôs o objetivo de torná-la um espaço de difusão da cultura chilena no momento em que o país vivia uma verdadeira expulsão de cérebros em massa. Através dessa revista cultural com clara orientação política, seus editores se propunham a lutar contra o "fascismo" imperante no Chile. A ideia era ser uma luz em meio ao "apagão cultural" existente no país e, ao mesmo tempo, servir como uma ponte entre os chilenos de "dentro" e os de "fora". Para alcançar tais objetivos, Volodia reuniu um grupo de destacados intelectuais no comitê editorial, além de colaboradores reconhecidos internacionalmente, majoritariamente chilenos, mas contou também com intelectuais de outras nacionalidades, sobretudo, latino-americanos. Todos - membros do comitê e colaboradores - aceitaram participar da publicação sem receber remuneração por seus trabalhos, o que era uma forte demonstração de solidariedade à causa chilena, tendo em vista que muitos eram intelectuais renomados e viviam de seus escritos. O único que recebia remuneração para confeccionar a Araucaria era Orellana, secretário de redação, dedicando-se exclusivamente a ela durante seu exílio. Segundo ele, os recursos para a manutenção da revista eram oriundos do PCCh já que os das assinaturas eram escassos (ORELLANA, 2007).

Com sede estabelecida em Paris, numa pequena sala cedida pelo jornal L'Humanité (pertencente ao Partido Comunista francês), e impressa em Madri, a Araucaria de Chile foi lançada no primeiro trimestre de 1978. Em seu primeiro número constavam apenas os nomes do diretor Volodia Teitelboim e do secretário de redação Carlos Orellana; não foi publicada qualquer referência a um comitê de redação, e na última página foram devidamente apresentados todos os colaboradores daquele número: o poeta Alfonso Alcaide, os renomados escritores Mario Benedetti, Julio Cortázar e Luis Enrique Delano, o médico e escritor Alfonso González Dagnino, o jornalista Eduardo Labbarca Goddard, o professor de literatura e ensaísta Hernán Loyola, o historiador e membro do Comitê Central do PCCh Hernán Ramírez Necochea, e os consagrados artistas plásticos Jose Balmés, Roberto Matta e Guillermo Nuñez. A autora da capa do primeiro número foi Gracia Barrios. O rosto impresso na capa de estreia de Araucaria evoca uma de suas obras mais conhecidas intitulada Multitud III, que após o golpe desapareceu e, somente 29 anos depois, foi reencontrada. No desenho dessa capa pode-

Revista Eletrônica da ANPHLAC, n.10, p. 83-125, jan./jun. 2011. http://revista.anphlac.org.br/index.php/revista 
se identificar a influência do expressionismo tanto no traço da artista, bastante marcado, quanto na expressão de violência do grito representado no rosto desenhado.

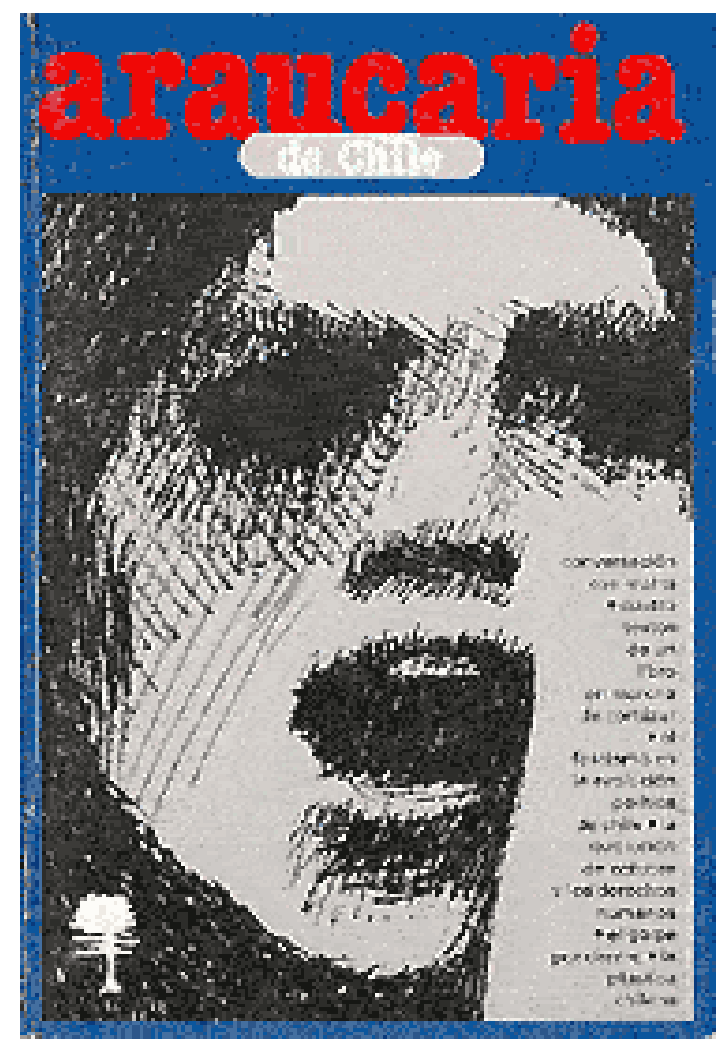

Ilustração 1: Capa da Araucaria de Chile $n^{\circ} 1$ autoria de Gracia Barro. Fonte: www.memoriachilena.cl

Segundo indicou Tânia Regina de Luca, para estudar um periódico tipo revista há um conjunto de características físicas e organizacionais às quais se deve atentar (DE LUCA, 2005 p. 115). A revista Araucaria era uma publicação trimestral que circulou do início de 1978 até 1990. Cada número continha, em média, 220 páginas em formato de livro (13,5 cm de largura por $21 \mathrm{~cm}$ de altura). Era impressa em papel simples e apenas a capa era colorida. ${ }^{4}$ Todos os seus números continham ilustrações assinadas por grandes nomes das artes plásticas chilenas como Jose Balmés e Roberto Matta, entre outros, e fotografias, em menor número, geralmente do Chile sob Pinochet. A organização das ilustrações estava a cargo do fotógrafo Fernando Orellana, filho de Carlos Orellana.

A revista publicou, nos doze anos de existência, mais de 10 mil páginas. Segundo Orellana, o PCCh não mediu esforços, inclusive financeiros, para constituir

\footnotetext{
4 Apenas o primeiro número de Araucaria publicou imagens coloridas nas páginas internas. Eram reproduções de algumas obras de importantes artistas plásticos, dentro da Seção Capítulos de la Cultura Chilena sobre artes plásticas.
}

Revista Eletrônica da ANPHLAC, n.10, p. 83-125, jan./jun. 2011. http://revista.anphlac.org.br/index.php/revista 
uma frente cultural na guerra contra a ditadura. ${ }^{5}$ Além de financiar a publicação, disponibilizou sua infraestrutura em vários países para distribuí-la, mas foi o empenho dos militantes que possibilitou a circulação da revista em condições excepcionais (ORELLANA, 2002, p. 344).

A Araucaria poderia ser adquirida também através de assinatura anual de quatro números. De acordo com o informe publicado no número 6 (meados de 1979), ela custava U\$15, e, segundo o número 38 (meados de 1987), custava U\$29. No segundo aniversário da revista, Orellana publicou uma crônica contando aos leitores que a Araucaria havia duplicado sua tiragem em relação ao primeiro número ${ }^{6}$ e que chegava a mais de 40 países, incluindo alguns poucos números enviados ao Chile.

Um dos objetivos da Araucaria era instalar, quando possível, sua redação no Chile. Desde seu segundo número, apareceram, constantemente, nas seções de cartas $D e$ los lectores, Documentos ou ainda Cartas de Chile, mensagens enviadas à redação informando sobre a leitura da revista através de empréstimos ou de cópias de seus artigos que corriam de mão em mão. Segundo Orellana, em agosto ou setembro de 1979, Pinochet exibiu uma revista Araucaria em um pronunciamento na televisão como prova de que ideias subversivas entravam no país clandestinamente (ORELLANA, 1994, p. 26; idem, 2002 , p. 339); fato que foi muito importante para os membros da revista, pois provava a eficácia de seu trabalho. Na seção De los lectores da revista 28 (4 trimestre de 1984) há uma fotografia enviada pelo leitor "AC"de Santiago, de uma livraria em cuja vitrine estavam expostas revistas Araucaria e livros que traziam nas capas as figuras de Allende e de Víctor Jara. A revista agradeceu a foto esclarecendo que, após a declaração do estado de sítio, fora novamente proibida a entrada do periódico no país (AC, Araucaria, n. 28, 1984, p. 7).

\footnotetext{
5 Orellana não soube precisar o custo de produção da revista Araucaria, do qual retirava seu salário (era o único dedicado integralmente ao labor na revista), a impressão e a distribuição. Mansilla fez uma estimativa de que cada número custava 20 mil dólares, quantia esta não completamente recuperada com as vendas. (ORELLANA, 2007; MASILLA, 2007).

6 A tiragem não era informada na publicação, mas, em conversa com Mansilla e Orellana, fui informada que a tiragem média era de três mil exemplares, porém os primeiros números devido à alta procura chegaram aos cinco mil exemplares. (ORELLANA, 2007; MASILLA, 2007).
}

Revista Eletrônica da ANPHLAC, n.10, p. 83-125, jan./jun. 2011. http://revista.anphlac.org.br/index.php/revista 


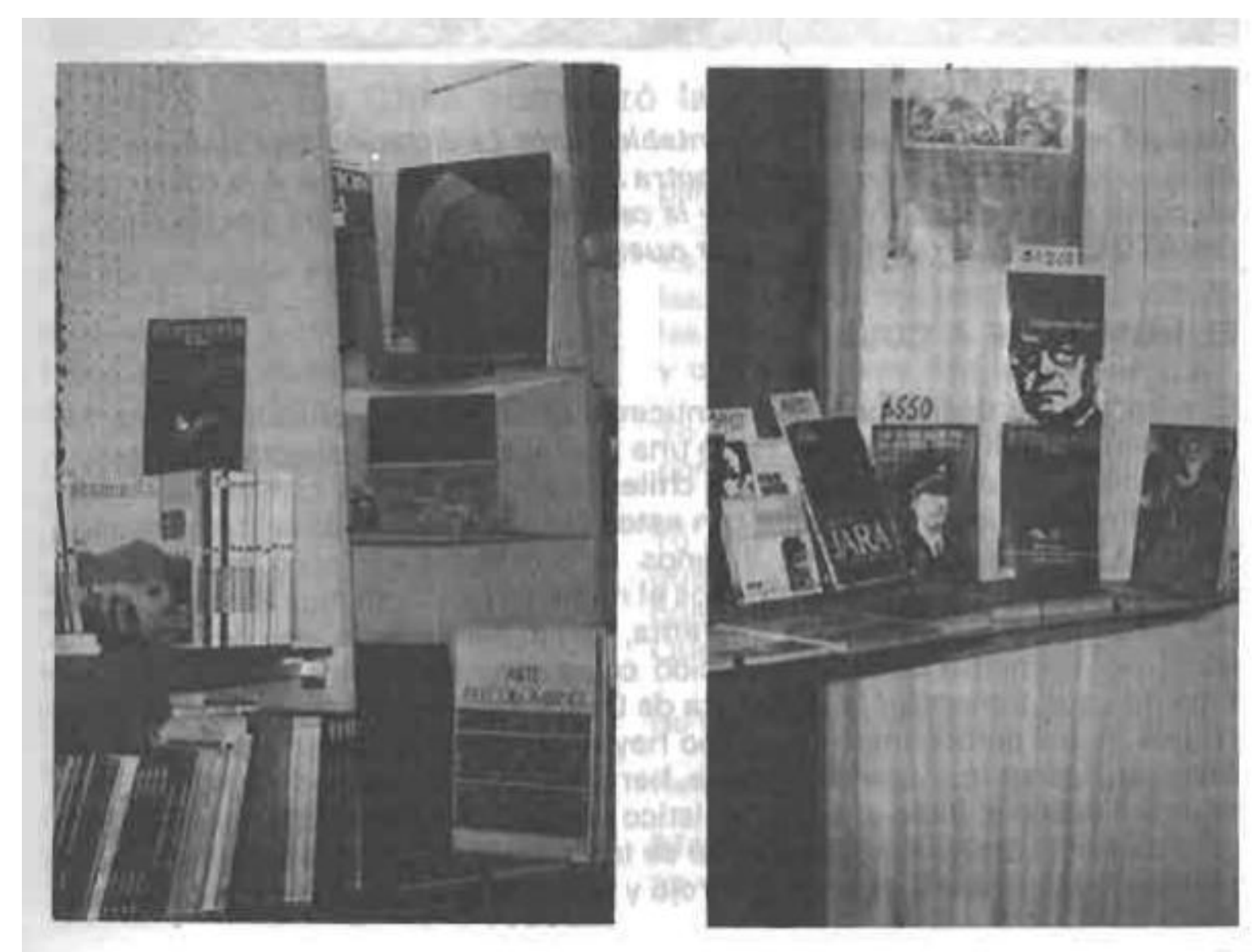

Ilustração 2: fotos enviadas pelo leitor "AC" de Santiago, publicadas na Araucaria 28, p.7. Fonte: www.memoriachilena.cl

Na metade de 1988, com o acerto da participação da oposição no plebiscito anunciado pelo governo Pinochet, crescia a expectativa em relação ao fim exílio. Um comitê de amigos da revista Araucaria foi instalado no Chile e presidido por Fernando Castillo Velasco, ex-reitor da Universidade Católica, que organizou uma homenagem à revista. Em cerimônia realizada em 27 de maio de 1988, foi anunciado, nessa homenagem, o ingresso no comitê de redação de um grupo de intelectuais que haviam retornado ao Chile, como Ligea Baladares, Virginia Vidal, Omar Lara, Guillermo Quiñones, e também de Hernán Soto e Pamela Jiles, que não estiveram exilados. A ideia era facilitar a transferência da publicação para o país tão logo saísse o resultado do plebiscito (TEITELBOIM, 1988, p. 185-189).

Depois da confirmação do resultado do plebiscito, a edição 44 da revista trouxe uma pequena nota intitulada Araucaria de Chile en Chile, lamentando o atraso de meses daquela edição e comunicando que seria o último número da revista publicado no exílio (Araucaria, n. 44, 1988, p. 6). Contrariamente ao anunciado, foram publicados ainda

Revista Eletrônica da ANPHLAC, n.10, p. 83-125, jan./jun. 2011.

http://revista.anphlac.org.br/index.php/revista 
mais três números da revista no exílio. Segundo Orellana, houve muitas dificuldades em relação a essas publicações porque o número de assinantes havia caído sensivelmente, em virtude das expectativas de retorno ao país (Orellana, 2007).

Publicada com atraso, a última revista apenas chegou ao público no início de 1990. O número duplo 47/48 apenas veio à luz graças à solidariedade dos espanhóis, pois os fundos necessários foram arrecadados por meio de um evento realizado em Barcelona cujo organizador foi o escritor Manuel Vazquéz Montalbán. ${ }^{7}$

Segundo Orellana e Mansilla, quando lançaram o último número já tinham consciência de que seria muito difícil dar continuidade a uma publicação daquele caráter no Chile dos anos 90, visto que, numa "sociedade de mercado", não haveria público interessado. Ademais nenhuma editora comercial apostaria numa revista cultural de cunho político tão claro, naquela transição em que prevaleceu a tese da "culpa compartilhada" ${ }^{8}$ do golpe. Por outro lado, no Partido Comunista, apesar de Volodia ter assumido o cargo de secretário geral em 1989, o grupo de intelectuais da Araucaria acabou se afastando, pois não havia mais espaço no Partido para seus projetos.

\section{A cultura chilena na revista Araucária}

A cultura chilena era o eixo da revista Araucaria, que publicou debates, entrevistas com artistas e suas obras (poesias, contos e trechos de romances). Artistas plásticos renomados foram responsáveis pelas suas capas e ilustrações. Veremos, então, como cada manifestação cultural (cinema, música, literatura, artes plásticas e teatro) foi abordada na revista, bem como os contrastes entre os produtores culturais chilenos "de dentro" e os "de fora" do país.

Os debates culturais foram concentrados na seção Temas, publicada em 44 das

$7 \mathrm{O}$ evento contou com as participações do instrumentista chileno Eulogio Dávalos e do representante da Nova Canção Catalã Lluis Llach, e com a colaboração, inclusive financeira, da deputação e o Ayuntamiento de Barcelona, dos Ayuntamientos de Sant Feliú y el Prat de Llobregat, do Ayuntamiento de Córdoba e da Universidade de Málaga. (Los adioses a/de España. Araucaria de Chile, n. 47-48, Madrid: Ediciones Michay, p. 7-11, $4^{\circ}$ trimestre 1989).

8 De acordo com essa tese "todos" teriam sido responsáveis pelo golpe de Estado, pelo radicalismo tanto da esquerda quanto da direita, o que escamoteia o fato de que quem atropelou a legalidade foi a direita. Os defensores dela omitem sua principal implicação: se todos foram responsáveis, logo ninguém deveria ser punido, porque seria "injusto" punir apenas um lado, ou seja, valoriza-se a necessidade de unificar o país em detrimento da necessidade de se fazer justiça, punindo os crimes cometidos pela ditadura. Esta tese foi defendida pelos intelectuais e políticos que formaram a Concertación e acordaram a transição com a ditadura.

Revista Eletrônica da ANPHLAC, n.10, p. 83-125, jan./jun. 2011. http://revista.anphlac.org.br/index.php/revista 
47 edições da revista. Na seção Capítulos de la cultura chilena, que apareceu em dez números, foram publicados entrevistas e artigos sobre as principais vertentes da cultura chilena numa perspectiva histórica, relacionando-as com questões políticas e sociais de diferentes épocas. Na seção Textos, presente em todos os números, foram publicados poemas, contos e trechos de romances de destacados escritores como Guillermo Atias, Antonio Skármeta, José Donoso, Ariel Dorfman, Federico Schopf, e do diretor da revista Volodia Teitelboim, entre outros. ${ }^{9}$

As manifestações culturais discutidas em Araucaria estavam, em sua maioria, profundamente sintonizadas com a resistência e a denúncia dos crimes da ditadura no Chile, embora, nos editoriais e outros textos em que a revista expunha seus critérios para selecionar o que seria publicado, a qualidade estética viesse em primeiro lugar. Depois do golpe, grande parte dos artistas e intelectuais chilenos precisou sair do país; muitos foram presos, torturados e mortos, outros tiveram que trabalhar em outras áreas devido à censura. Num país onde livros eram queimados em praça pública, qualquer manifestação cultural era sinal de rebeldia e resistência ao "apagão cultural". O engajamento dos artistas contra a censura férrea dos militares mostra que a História Cultural e a História Política são indissociáveis no caso chileno.

O que se define por cultura chilena na revista Araucaria é o conjunto das manifestações artísticas produzidas por chilenos exilados ou dentro do país, sendo estas últimas sempre muito celebradas como formas de resistência ao silêncio imposto pela ditadura. Em muitos momentos, ressaltou-se a diferença no tom utilizado pelos artistas que produziram cultura dentro e fora do Chile: enquanto os primeiros precisaram recorrer a mensagens cifradas e metáforas para escapar da censura, entre os exilados predominaram a denúncia direta da violência e a expressão do medo e dos dramas vividos na situação do exílio. Apesar das diferenças, em ambas se nota um estilo testemunhal que revela o desejo de deixar registros das experiências vividas. Esse tipo de narrativa foi muito valorizada pela própria revista Araucaria, cujo Índice aponta a publicação de cinquenta testemunhos, contabilizados apenas na seção intitulada Testimonios, sem levar em conta entrevistas e narrativas publicadas que continham o mesmo tom testemunhal.

Cabe destacar a presença constante dos autores chilenos agraciados com o

9 Cabe esclarecer que, neste artigo, o foco são as críticas e debates do período e não a análise literária dos trechos de romances, peças e poesias publicadas pela revista.

Revista Eletrônica da ANPHLAC, n.10, p. 83-125, jan./jun. 2011. http://revista.anphlac.org.br/index.php/revista 
prêmio Nobel — Gabriela Mistral (1945) e Pablo Neruda (1971) —, muito festejados com artigos especiais a cada efeméride, como o centenário de Mistral e os 75 anos de Neruda. Naquele momento de embate contra a ditadura era imprescindível evocar seus legados literários e suas participações nas lutas políticas.

A presença de Pablo Neruda na revista foi muito expressiva devido às suas posições políticas e ao significado de resistência que sua obra adquiriu após o golpe. Foram publicados 28 artigos sobre sua produção ou biografia, além de cinco textos de sua própria autoria, sem contar as diversas vezes em que foi evocado em entrevistas ou testemunhos. Neles, havia relatos sobre suas ações políticas, como por exemplo: em 1939, organizou o barco Winnipeg que levou para o Chile cerca de dois mil republicanos espanhóis fugidos do franquismo; em 1945, filiou-se ao Partido Comunista (chegou a ser membro do comitê central); em 1948, proferiu, no Senado, o discurso Yo acuso $^{10}$ no qual denunciou a traição do governo de González Videla (1946-1952) ao Partido Comunista Chileno. Por causa desse discurso, Neruda foi perseguido e vivenciou uma fuga espetacular que consistiu na travessia dos Andes a cavalo em direção ao exílio na França; anos mais tarde, apoiou fortemente o governo Allende ocupando o cargo de embaixador na França até meados de 1973, quando o agravamento de seu estado de saúde o fez retornar ao Chile. Até mesmo as circunstâncias de seu falecimento, dias após o golpe militar, reforçaram o mito: seu cortejo fúnebre foi considerado o último ato público da Unidade Popular e o primeiro da Resistência, raríssima ocasião, em muitos anos, que uma multidão se reuniu e cantou a Internacional Comunista e o Hino da Unidade Popular. Não é de estranhar que Neruda tenha sido apresentado constantemente na revista como o exemplo de intelectual engajado na luta pela justiça social e democracia, além da qualidade estética de sua obra muito valorizada em Araucaria.

Em alguns artigos, a revista exibiu referências importantes do desenvolvimento cultural chileno, situadas num panorama bastante amplo. No número 10, Ariel Dorfman apresentou um ensaio sobre a relação dos produtores culturais com o Estado chileno, comparando os períodos anterior e posterior ao golpe militar (DORFMAN, 1980). Segundo o autor, a atuação do Estado como grande mecenas teve início com o governo

10 A escolha do título do discurso de Neruda é uma referência direta ao do francês Émile Zola (J'accuse) durante o famoso caso Dreyfus, que suscitou a manifestação pública do intelectual em defesa do militar judeu francês Dreyfus acusado injustamente de ser um espião alemão.

Revista Eletrônica da ANPHLAC, n.10, p. 83-125, jan./jun. 2011. http://revista.anphlac.org.br/index.php/revista 
da Frente Popular (1938-1942) e alcançou o apogeu durante o governo da Unidade Popular (1970-1973), quando os produtores culturais engajados nos projetos de construção do socialismo encontraram trabalho dentro dos diversos órgãos estatais e nas universidades. Depois do golpe, a cultura deixou de ser tratada como um direito para tornar-se um artigo a mais a ser negociado no mercado. Para Dorfman, as consequências dessa brusca transformação foram, de um lado, a autonomização dos intelectuais em relação ao Estado e, de outro, a atomização dos trabalhos artísticos, que já não contavam com iniciativas estatais capazes de unificar e divulgar a cultura por todo o país.

\title{
Da universidade produtora de cultura à "contrarreforma" da ditadura
}

Os responsáveis pela revista entendiam que as universidades tinham sido até 1973 fundamentais para a produção cultural no país. Por esse motivo, a "contrarreforma" universitária promovida pela ditadura foi intensamente debatida em onze números do periódico. Em todos eles, o diagnóstico era que as universidades deixaram de ser pensadas como um lugar onde deveriam prevalecer o pensamento crítico, a pesquisa, a produção e difusão cultural.

Cabe mencionar um discurso de Pinochet pronunciado em 1982 no qual esclareceu as razões da Reforma Universitária realizada anos antes. Tal discurso permite compreender melhor o sentido dos questionamentos expressos na revista. O ditador afirmou:

\begin{abstract}
con tal propósito ha existido una especial preocupación por dar al cuerpo académico la debida jerarquía, considerando mecanismos de selección que garanticen la idoneidad de sus miembros, y estableciéndose fórmulas de conducción universitaria, que (...) destierran los perniciosos mecanismos electorales que permitieron que las Universidades se transformaram en centros de disputas del poder por parte de grupos politicos, los que terminaron convirtiéndolas en instrumentos de violencia social y desenfrenado activismo partidista. (Pinochet, 1985, p. 203).
\end{abstract}

As referidas críticas da Araucaria denunciavam não apenas a despolitização da universidade, mas, sobretudo, a transformação do sistema universitário chileno em negócio a ser explorado por empresários e território de patrulhamento ideológico. Tais denúncias foram feitas através de entrevistas com ex-reitores, docentes - tanto os que

Revista Eletrônica da ANPHLAC, n.10, p. 83-125, jan./jun. 2011. http://revista.anphlac.org.br/index.php/revista 
permaneceram quanto os que saíram por motivos políticos ou salariais -, e com estudantes que testemunharam o ambiente de vigilância política.

O crítico literário Alfonso Calderón, em seu ensaio La cultura en Chile (19731983): las vantajas de la mala fe, interpretou o desmonte dos aparatos culturais no Chile. Processo que começou pelas universidades como uma ação orquestrada, por um lado, pela necessidade de controle dos locais de produção de conhecimento e arte pela ditadura, e por outro, com o objetivo de abrir mais um mercado para a exploração comercial da cultura, desonerando o Estado conforme a lógica neoliberal (CALDERÓN, 1983). Assim como Dorfman, Calderón verificou que uma das consequências da censura e do fechamento da academia para as atividades culturais foi a criação pelos próprios artistas de pequenos espaços de circulação cultural, que resultou na autonomização e atomização da cultura no Chile.

\section{O “apagão" cultural}

Com o fim do mecenato estatal para as atividades culturais e o clima de repressão instaurado em 1973, teve início o período conhecido como o “apagão cultural", que durou até aproximadamente 1976, quando, lentamente, os artistas retomaram suas atividades. Cabe lembrar que, em seu primeiro número, a revista Araucaria de Chile anunciou-se como uma luz no fundo do túnel; seis números depois ( $2^{\circ}$ trimestre de 1979), um artigo assinado por Samuel Guerreiro ${ }^{11}$ noticiava o acender das luzes (GUERREIRO, 1979). O autor mostrou como, no final dos anos 1970, os artistas que ficaram no Chile foram, gradualmente, retomando os espaços públicos através de pequenas iniciativas. Para Guerreiro, a principal atividade artística desse reflorescimento era a música, com as guitarras esquineras, que consistiam em grupos de jovens que se reuniam para tocar nas esquinas ou em pequenos eventos de solidariedade promovidos pela Vicaria de Solidariedad para ajudar os órfãos, as viúvas e os presos da "guerra interna" promovida pela Junta Militar. O autor fez referência a feiras onde artesanatos produzidos pelos presos eram vendidos, poesias eram recitadas e espetáculos teatrais apresentados, inicialmente em pequenas reuniões que tinham como

11 Samuel Guerreiro foi o pseudônimo utilizado por Manuel Guerreiro, professor assassinado pela ditadura em março de 1985 junto com o sociólogo Jose Manuel Parada e o desenhista Santiago Nattino no tristemente conhecido "caso dos degolados".

Revista Eletrônica da ANPHLAC, n.10, p. 83-125, jan./jun. 2011. http://revista.anphlac.org.br/index.php/revista 
objetivo despertar o espírito de solidariedade e estimular a resistência contra a ditadura.

Corroborando com o cenário descrito por Guerrero, a revista publicou ainda os testemunhos de Jose Morales e do poeta Raul Zuritta. O primeiro (MORALES, 1978) afirmou que 1974 fora o pior momento para a cultura, quando houve um apagão de fato, mas que, em 1975, os músicos já começaram a se organizar e a promover concertos para arrecadação de comida e roupas para a Vicaria de Solidaridad. Dessa forma, lentamente o folclore foi retomado e as queñas e charangos $^{12}$, mesmo proibidos por lei, ganhavam as ruas, e grupos organizados conseguiram abrir algumas peñas ${ }^{13}$ para que se apresentassem. Em decorrência, até os meios de comunicação mais reacionários como o diário El Mercúrio tiveram que abrir espaço para os cantores populares. Zurita (1986), por sua vez, creditou esse reflorescimento a um segundo golpe: foi a percepção de que a ditadura seria longa que levou os artistas a se reorganizarem. Para ele, o apagão teria sido o interregno de atonia e medo entre os "dois" golpes.

As manifestações culturais que mais se destacaram no Chile após o ressurgimento das atividades, segundo os artigos da Araucaria, foram o teatro e a poesia. Talvez isso se explique porque se tratava de expressões artísticas que, ao contrário dos festivais de música, não reuniam um número grande de público espectador, o que não seria tolerado pela ditadura, nem requeriam somas importantes de dinheiro para as montagens e apresentações; estas eram divulgadas dentro de pequenos circuitos conhecidos. Na metade final dos anos 1980, outras manifestações artísticas foram conquistando maior espaço.

\section{As artes e a reconquista de espaços}

\section{Literatura}

12 Instrumentos andinos muito utilizados pelo movimento da Nova Canção Chilena (NCCh), cujo cunho engajado das letras e a militância política dos artistas o identificam à campanha e ao governo da Unidade Popular (1970-1973). Mais informações sobre a NCCh: SILVA, Ecça Pereira. La nueva Canción Chilena: um encontro entre a arte e a política. São Paulo: FFLCH/ USP FAPESP, 2003. (Mimeografado).

13 Pequenos restaurantes que serviam empanadas e vinho, onde artistas apresentavam suas canções e poesias. A primeira peña do Chile foi inaugurada em 1965, na Calle Carmen 365, era a Peña de los Parra, pertencia aos irmãos Isabel e Angel Parra, filhos de Violeta Parra, uma das maiores artistas populares do Chile. Nesses espaços surgiu a Nova Canção Chilena

Revista Eletrônica da ANPHLAC, n.10, p. 83-125, jan./jun. 2011. http://revista.anphlac.org.br/index.php/revista 
A literatura foi a arte que pôde contar com uma ancoragem mais profunda, porque, segundo alguns críticos como Marcelo Coddou (1981) e o poeta Federico Schopf (1980), não houve um grande movimento, nessa área, vinculado de modo explícito ao governo da Unidade Popular, como ocorreu em outras artes. Para ambos, o golpe representou um choque profundo com a realidade do país, e, desde então, aqueles que faziam uso da pena passaram a expressar as angústias do momento vivido no exílio ou dentro do país. Tanto a poesia quanto a prosa denunciavam e testemunhavam o que não se podia calar, mas que, ao mesmo tempo, era proibido. Em Araucaria número 4, o crítico literário Jaime Concha (1978) valorizou o testemunho como forma de resistência artística à ditadura. Desconhecidos recorreram a poemas, contos e narrativas para dar a conhecer ao mundo o drama chileno, e muitos escreveram também panfletos anônimos. Concha acreditava que nesses momentos limites:

justamente porque la literatura y el arte en general son los depositarios de los deseos más nobles del hombre, de sus deseos más "humanos", es que es posible que ellas, en estas grandes ocasiones funerales, alienten y impulsen una vez más al trabajo político. (CONCHA, 1978, p. 147).

Assim, invertia-se a concepção de que a política deveria ser impulsora da arte. Num momento de luto, ao contrário, apenas a arte podia dar conta de denunciar os horrores e, a partir dela, gerar um ambiente de solidariedade e mobilização, principalmente fora do Chile.

Na mesma revista, o escritor e roteirista Antonio Skármeta (1978) comparou a narrativa chilena pós-golpe produzida dentro e fora do país. Segundo Skármeta, as obras escritas dentro do Chile tinham aspectos comuns ${ }^{14}$ : por motivos óbvios, não abordavam a temática política diretamente, mas apresentavam personagens em situações angustiantes, trágicas e paradoxais, lutando contra a solidão e o emparedamento. Já os livros publicados no exílio ${ }^{15}$ tinham em comum o fato de se apoiarem mais nas imagens sobre o Chile produzidas pela imprensa do que em experiências pessoais; além disso, seus protagonistas eram burgueses ou pequenos burgueses, e não "protagonistas y víctimas de la historia" como os trabalhadores chilenos que permaneceram no país. Os

14 Os romances escritos dentro do país analisados por ele foram: Dulces chilenos (1977) de Guillermo Blanco, El Picadeiro (1975) de Adolfo Couve, Paréntesis (1974) de Mauricio Wacquez, La orquestra de cristal (1976) de Enrique Lihn e El caudillo de Copiapó (1976) de Mario Bohamondes.

15 Skármeta analisou as seguintes obras escritas fora do Chile: Este lugar sagrado (1977) de Poli Delano, El paso de los gansos (1975) de Fernando Alegría, Le sang dans la rue (1978) de Guillermo Atias (traduzido mais tarde por La contracorriente), Chilex (1978) de Ariel Dorfman e Los invitados de piedra (1978) de Jorge Edwards.

Revista Eletrônica da ANPHLAC, n.10, p. 83-125, jan./jun. 2011. http://revista.anphlac.org.br/index.php/revista 
escritores que haviam participado da luta e, então, escreviam a partir do exílio referiamse àqueles trabalhadores distantes de forma excessivamente idealizada. Ao final, Skármeta salientou que muito se estava escrevendo sobre a sorte do Chile e que muitos inéditos de qualidade apareceriam em revistas como Araucaria ou Literatura Chilena en el Exilio.

Seguindo a mesma linha de comparação traçada por Skármeta, o crítico literário Alcides Jofré (1987) escreveu, no número 39 de Araucaria, sobre os romances chilenos que circulavam no país, usando como critério não apenas aqueles publicados dentro do Chile, mas também os que foram escritos no exílio e tiveram permissão para a entrada no país; analisou dezessete romances publicados entre 1974 e 1984. Seu trabalho de crítica concluiu que, naqueles romances, a linguagem política se tornou mais estética, ao passo que a linguagem artística se tornou mais política, apesar dos receios de que uma fosse instrumentalizada pela outra. Isso porque a quebra da institucionalidade apresentou desafios em todos os campos que envolvem a produção cultural, como, por exemplo: a reinvenção da linguagem, que ocorreu para que a sua função de comunicação se cumprisse a despeito da censura; a transformação da arte em sinônimo de mercadoria, que acabou por converter a literatura em artigo de luxo. Ou seja, as condições políticas do país ao marcarem a produção artística daquele momento tornaram-na fonte histórica importante para compreensão dessas mesmas condições.

A crítica literária Soledad Bianchi, em artigo publicado na seção Libros da Araucaria número 7 - Poesia chilena: la resistencia y el exilio (1979) —, mostrou a fragmentação da literatura chilena como efeito da cisão entre os chilenos de "dentro" e os "de fora"; considerava as narrativas de caráter testemunhal como possível ponto de unidade entre as duas literaturas. Bianchi referiu-se a alguns livros de poesias que, editados no exílio (em especial uma coletânea publicada na Itália, Il sangre e la parole em 1978), tinham o mérito de reunir poemas feitos dentro e fora do Chile. O impacto da referida coletânea podia ser medido pelo poema de abertura Estadio de Chile, atribuído a Víctor Jara. Os poemas publicados, muitos anônimos, impressionaram Bianchi pela delicadeza e precisão com que descreviam situações de crueldade extrema, aumentando ainda mais a sensação de horror.

No início dos anos 1980, surgiu uma nova geração de escritores chilenos, que beiravam os 30, cujas primeiras experiências literárias foram marcadas pela repressão. Na Araucaria número 12, a seção Textos foi integralmente dedicada a esses jovens 
escritores e contou com a participação de oito deles, dos quais seis estavam exilados. Um deles, José Leandro Urbina (1980), compilou textos literários e os reorganizou para publicação em Araucaria com o intuito de divulgar seus trabalhos através da revista que circulava em cinco continentes. Frisou, em nota, que a temática de todos os textos publicados girava em torno da sensação de sufocamento dentro do país ou da solidão no exílio.

A revista Araucaria esteve também aberta a intelectuais não alinhados ao PCCh, como o professor da Universidade de Minnesota René Jara (1987), que analisou três novelas, a saber: La casa de los Espíritus (1982) de Isabel Allende, Coral de Guerra (1979) de Fernando Alegría e La visita del presidente o adoraciones fálicas en el valle del pueblo (1983) de Juan Villegas. O título do ensaio, Huellas de la esperanza, foi esclarecido na conclusão em que o autor expôs a novidade apresentada por tais novelas: na tragédia, estava o fio da esperança. Explicou que a esperança residia no fato de que, nesses romances, se admitia o que era negado no plano do real: a cota de responsabilidade de "todos" pelo golpe de Pinochet. A tese da "culpa compartilhada" defendida por setores que aceitaram a legalidade dos golpistas e pactuaram com a transição orquestrada por Pinochet estava presente no comentário do autor. A publicação desse ensaio demonstra, portanto, a abertura de Araucaria para as mais diversas tendências políticas, apesar de seu vínculo com o Partido Comunista, pois além da conclusão conciliadora, René Jara referiu-se ao governo Allende como uma "experiência populista", com sentido pejorativo.

A literatura produzida dentro do Chile sempre foi muito festejada pela revista Araucaria. Manuel Alcides Jofré (1985), residente no Chile, comentou o Colóquio de Literatura Chilena, realizado em Santiago entre 10 e 14 de dezembro de 1984, organizado pela Licenciatura em Instituto Superior de Artes y Ciencias Sociales (ARCIS), ressaltando a presença de especialistas em literatura que residiam no exterior: Luis Navarrete, Marcelo Coddou, Jaime Giordano, Grinor Rojo, Juan Durán e Fernando de Toro. O elo entre os de "dentro" e os de "fora" foi explicitado pela leitura de mensagens de importantes intelectuais exilados, como Ariel Dorfman, Fernando Alegría e Antonio Skármeta.

A revista entrevistou ainda o presidente do Sindicato dos Escritores do Chile Martín Cerda. Destacou-se a sua dificuldade em mobilizar os escritores que moravam no país para a luta contra a ditadura, sobretudo, no início das grandes manifestações. A

Revista Eletrônica da ANPHLAC, n.10, p. 83-125, jan./jun. 2011. http://revista.anphlac.org.br/index.php/revista 
fim de fortalecer o sindicato, o escritor focou as atenções nos jovens, principais afetados pela ditadura.

A dificuldade de "engajar" os escritores, especialmente aqueles exilados que conseguiam editar seus livros no país, pode ser ilustrada com o caso de José Donoso. Seu romance Casa del Campo abarca o período que vai da Unidade Popular até o golpe. A obra se caracteriza por uma crítica política e social, através de uma narrativa repleta de elementos fantásticos. Contudo em entrevista publicada em Araucaria, Donoso (1979) se ateve aos aspectos estéticos do livro; reconheceu que algumas personagens haviam sido construídas com base em pessoas reais, mas evitou maiores comentários, pois seu livro ainda aguardava a permissão para ser comercializado no Chile e, assim, para evitar problemas com a censura, o autor não fez referências diretas ao regime.

\section{Teatro}

O teatro chileno foi assunto da seção Capítulos da Cultura Chilena em três oportunidades e, em outras, da seção Temas. Como todas as demais manifestações artísticas, sofreu com a censura e a repressão, contudo, a partir das entrevistas e das análises publicadas na revista Araucaria, verifica-se que a atividade teatral foi rapidamente reorganizada e se manteve com certa regularidade dentro do país. No exílio, surgiram, em diversos países, grupos teatrais chilenos, sobre os quais a revista também noticiou, em entrevistas com atores e diretores.

Em Araucaria número 6, na seção Capítulos da Cultura Chilena, foi transcrita uma entrevista coletiva com três dos principais nomes do teatro chileno, Roberto Parada, Maria Teresa Fricke e Rubén Sotoconil (1979), cujo tema principal referia-se à fundação do Teatro Experimental da Universidade do Chile em 1941. Esse evento fez parte de um momento importantíssimo da vida intelectual e cultural chilena: estava no poder a Frente Popular, cuja eleição havia mobilizado a intelectualidade antifascista durante os anos 1930 e, no bojo dessa onda, foram fundados, além do grupo teatral, o balé nacional e a orquestra sinfônica. Durante a entrevista coletiva, os atores lembraram as preocupações políticas e sociais do período, que resultaram na organização do grupo e na escolha do repertório. Alguns anos depois, o trabalho desse grupo teatral foi incorporado às carreiras da universidade, com a criação do Instituto de Teatro da Universidade do Chile, ITUCh, alcançando status profissional.

Revista Eletrônica da ANPHLAC, n.10, p. 83-125, jan./jun. 2011. http://revista.anphlac.org.br/index.php/revista 
A história do teatro chileno contada na Araucaria também esteve relacionada à história das lutas da classe operária. Luis Emílio Recarraben Serrano, fundador do Partido Obrero Socialista (posterior Partido Comunista Chileno), além de sindicalista, foi ator, diretor de teatro e poeta; nos sindicatos e gráficas que dirigiu, criou espaços para o desenvolvimento cultural dos operários. Desse modo, segundo esclareceu Pedro Bravo Eliozondo (1982), em Araucaria, o teatro foi muito importante para a formação ideológica da classe trabalhadora chilena que, interpretando ou assistindo a peças de conteúdo político, começou a tomar consciência das contradições da sociedade. Pode-se afirmar que essa atenção do movimento obrero dedicada ao teatro deixou marcas bem profundas tanto nas classes populares quanto no movimento teatral.

Eliozondo (1981) enumerou uma série de montagens realizadas desde 1974, mostrando que alcançaram maior vigor a partir de 1976. A partir de então, afora o teatro profissional, retomou fôlego o teatro amador nas poblaciones, que encenavam peças com a abordagem dos seguintes temas: a repressão, o desemprego, a mercantilização das relações humanas, entre outros. Nesse cenário, a solidariedade entre as pessoas era a única saída possível, e a arte - especialmente o teatro - constituiu um caminho para reforçá-la. Para o autor, esse crescimento do teatro no Chile, mesmo sob a ditadura, significou que, além de "levar arte para o povo", os artistas estavam "fazendo arte com o povo".

O teatro poblacional, segundo Diego Barros Muñoz (1985), foi construído como uma alternativa humanista à violência política e à cultura consumista disseminadas durante a ditadura. Assim, a prática teatral contribuiu para a formação de um espaço em que os pobladores poderiam articular, via experiência artística, um imaginário diferente daquele imposto pela ditadura. Nesse espaço, os pobladores eram os sujeitos das transformações históricas ainda em curso, cujo desenlace final estaria ainda muito longe da opressão do presente. O autor esclareceu que a mensagem de "tornar-se sujeito" de um coletivo, implícita em grande parte das obras apresentadas, significava um caminho para superar problemas enfrentados pelos pobladores, como o alcoolismo, a prostituição, o servilismo, a alienação e o consumismo. Tratava-se de um teatro político, não só pelo que comunicava em cena, mas pela postura dos próprios pobladores "atrevendo-se" a fazer e a "consumir" arte com vistas a transformar a realidade ultrapassando as dificuldades. Alguns dos muitos grupos mencionados por Barros Muñoz foram: Amanecer (de Maipú), Tea Tierra (Villa Francia), Expresión de la verdad 
(Herminda de la Victória), La puerta (La Renca).

A existência de uma cena teatral no Chile sob o regime militar é atestada pelo artigo de Grinor Rojo El teatro chileno bajo el fascismo (1983). Ele vivia no exterior, e esteve no Chile durante um mês (de 15/08 a 15/09 de 1982), ocasião em que assistiu a 24 peças teatrais, a partir das quais descreveu o cenário teatral chileno, atentando sempre para o tipo de público que frequentava cada tipo de espetáculo. Rojo afirmou que não havia, no cenário teatral chileno, peças ou grupos que defendessem explicitamente o ideário da ditadura, contudo havia certos grupos comerciais, alguns até mesmo que transplantavam montagens da Broadway e outros remontando antigos sucessos dos anos 1940 aos 1960. Rojo explicou a grande quantidade de remontagens como uma estratégia de sobrevivência dos grupos, pois as peças tinham sido escritas em momentos de crise, e, de algum modo, levavam o público a refletir sobre o que acontecia no país. Entretanto, para Grinor Rojo, o único lugar onde o texto e demais aspectos da montagem faziam uma crítica radical à sociedade chilena diante de um público disposto a uma reflexão séria e provocativa sobre a ditadura era a Cia. Teatral $E l$ Telón, dirigida pelo dramaturgo Juan Radrigán.

Radrigán concedeu uma entrevista a Jose Miguel Varas publicada no número 31 da revista (RADRIGÁN, 1985). Diferente de muitos artistas, Radrigán era oriundo da classe trabalhadora: começou a trabalhar aos treze anos como carregador, depois como carpinteiro e operário fabril em diversas empresas; na ocasião do golpe, era dirigente sindical e foi automaticamente demitido, convertendo-se em desempregado "crônico". Sua primeira peça de sucesso foi baseada num evento biográfico. Após um longo período desempregado, Radrigán começou a vender livros nas ruas e conseguiu montar uma banca na Praça Almagro, mas, algum tempo depois, foi despejado por não ter pagado uma licença da qual nunca tivera conhecimento (!). Esse evento "kafkaniano" foi, então, tema da peça intitulada Testimonios sobre la muerte de Sabina, estreada em 1979. Radrigán obteve sucesso e passou a escrever novas obras. Para serem encenadas, eram submetidas ao crivo das companhias teatrais que, por medo da censura, atenuavam seus textos. Segundo Radrigán, tal medo soava exagerado, pois até o momento da entrevista (provavelmente julho de 1985) apenas duas peças haviam sofrido censura direta do regime: Mijita rica e Lo crudo, lo cocido y lo podrido. Possivelmente por desconhecimento, o autor não mencionou a brutal repressão desencadeada contra a Cia El Aleph em 1974 (explicada a seguir). Para vencer esse obstáculo Radrigán formou,

Revista Eletrônica da ANPHLAC, n.10, p. 83-125, jan./jun. 2011. http://revista.anphlac.org.br/index.php/revista 
junto com outros dramaturgos e atores, a companhia El Telón; esclareceu que, para contornar problemas financeiros, o grupo decidiu montar peças baseadas em importantes obras literárias a serem vendidas em escolas, o que deu resultado.

Destino diverso teve o ator Oscar Castro, que utilizou sua arte como arma para enfrentar a ditadura. Isso lhe custou a perda da liberdade e o assassinato do companheiro de trabalho e cunhado Juan MacCleod. Oscar foi preso num campo de concentração e relatou essa experiência em entrevista concedida a Ariel Dorfman, quando já estava no exílio (CASTRO, 1979). Segundo Castro, sua companhia El Aleph, montou, ainda em 1974, uma peça intitulada Y al principio existía la vida baseada em textos bíblicos com referências veladas à Unidade Popular. Para a estreia, foram enviados convites a todas as embaixadas como estratégia de defesa contra eventuais agressões: todas compareceram em peso. A peça foi muito elogiada pela crítica, até mesmo pelo El Mercúrio.

O espetáculo ficou em cartaz entre outubro e novembro de 1974, quando Castro e outros membros do elenco foram presos. Castro foi enviado primeiro para a Villa Grimaldi, conhecido centro de tortura, e, depois, para o campo de concentração de Tres Álamos. Relata que ali os detidos se organizaram em comissões: bem-estar, esportes, artesanato e cultura. Castro fez parte desta última e afirmou que sua atividade ligada ao teatro contribuiu para que o regime não alcançasse o objetivo de "quebrar" moralmente os presos. Continuou trabalhando com teatro nos diversos campos de concentração por onde passou por acreditar que sua arte melhorava seu próprio ânimo e dos demais prisioneiros.

A proposta da revista Araucaria de ter como único critério de exclusão as manifestações pró-pinochetistas se confirma nas entrevistas publicadas por personalidades do teatro chileno, pois divulgaram críticas feitas por artistas ao uso da arte como forma de militância política.

O dramaturgo Jorge Díaz que vivia desde 1965 na Espanha (então, sob o comando de Franco) declarou que o teatro nunca seria uma forma eficaz de luta política. E, ao final, da entrevista expressou sua amargura com o Chile, considerava-se parte da geração perdedora de 1968 que, com todo o seu idealismo e otimismo, havia sido derrotada pela repressão (DIAZ, 1985).

Foram entrevistados, também por representantes da revista, os atores Luis Alarcón (1985) e Tennyson Ferrara (LOPES CARMONA, 1985). Este último 
surpreendeu o entrevistador ao afirmar que a autocensura dos artistas poderia ser reputada mais rígida que a censura do regime. Disse ainda que um escândalo nos jornais era mais eficaz, politicamente, do que um sucesso de bilheteria, e referiu-se às vantagens da televisão em atrair o público para os teatros. Suas opiniões apontavam que, por um lado, a produção de arte engajada poderia não ser tão eficaz quanto se pensava, pois corria-se o risco de "pregar aos já conversos", e, por outro lado, que os meios de comunicação de massas, por mais criticados que fossem, deveriam ser utilizados na medida do possível.

Enfim, a revista Araucaria esforçou-se por divulgar o teatro feito no exílio e as transformações da dramaturgia produzida dentro do Chile. Assim, o teatro chileno espalhou-se pelo mundo através de importantes figuras que defenderam e divulgaram sua arte nas páginas da revista. Também teve espaço em Araucaria o teatro realizado pelas poblaciones, que funcionaram como centro de memória da experiência da UP e como arma de luta social e política. No outro extremo, cabe lembrar que a expressão teatral foi concebida como entretenimento por uma parcela da população que estava lucrando com a mercantilização radical da arte, em curso no próprio país.

\section{Cinema}

Inegavelmente a produção cinematográfica chilena aumentou de forma significativa no exílio. As tentativas de desenvolvimento dessa arte no governo da Unidade Popular não tiveram sucesso, mas essa experiência política acabou se tornando um dos grandes temas do cinema no exílio. A revista Araucaria, em sua proposta de ser irradiadora de cultura, entrevistou cineastas já consagrados como Patrício Guzmán, Raúl Ruiz e Miguel Littin; publicou ainda estudos sobre cinema chileno, embora sempre alertasse para o perigo da incompletude, pois havia cineastas chilenos produzindo em mais de 40 países. Dentro do Chile, as realizações cinematográficas aconteceram em menor número devido à falta de infraestrutura, impossibilidade de difusão e ação da censura; daí os poucos filmes realizados no período terem sido tão festejados pela publicação.

As primeiras referências ao cinema chileno foram publicadas na seção Capítulos de la Cultura Chilena no número 11 de Araucaria. Nela constam entrevistas com Raúl Ruiz e Patrício Guzmán, relatos de um debate sobre cinema chileno na URSS, a 
denúncia de Hélvio Soto sobre a censura sofrida por seu filme ainda no governo Frei (1964-1970) e comentários sobre filmografia chilena de exílio assinada por Jacqueline Mouesca.

A entrevista de Patrício Guzmán (1980) foi focada em suas atividades durante o governo da UP. Guzmán contou que vivia na Espanha desde 1966, voltou ao Chile em 1969, acompanhou, então, parte da campanha da UP e, daí, decidiu regressar para filmar "a" revolução, o que seria inédito, segundo ele. Formou uma equipe de três pessoas e rodou El primer año, da posse de Allende (1970) até a visita de Fidel Castro (1971). Nesse mesmo ano, ingressou na Chile Films, onde ficou responsável pelo núcleo de documentários: ministrou cursos e produziu programas. Guzmán recordou essa tentativa estatal de fomentar o cinema chileno como algo importante para a produção imagética do período. Os cineastas que estavam ali reunidos se espalharam em pequenos núcleos, mas todos mantiveram o compromisso revolucionário. Contou que, desde o episódio do Tancazo, em 1969, quando o câmera argentino Leonardo Henricksen filmou sua própria morte, percebeu que estava diante de uma situação extrema: filmaria ou uma guerra civil revolucionária ou um golpe "fascista".

Na mesma edição, há uma entrevista de Luis Bocaz com o cineasta Raúl Ruiz, que, ao contrário de Guzmán, teceu severas críticas ao projeto de cinema da UP e fez ressalvas em relação à filmografia produzida no exterior (RUIZ, 1980). Afirmou que, apesar do crescimento do cinema chileno no exílio, não havia unidade entre seus produtores. E quanto à produção patrocinada pela UP, denunciou o fato de que somente tiveram acesso aos fundos da Chile Films os cineastas ligados à Universidad de Chile ou Universidad Técnica de Estado, que, inclusive, produziram filmes medíocres. Acrescentou que a Chile Films era um exemplo, na área do cinema, da incapacidade de direção da UP de modo geral: todos brigavam com todos e a empresa foi nula em realizações. Para Ruiz, o cinema chileno fora impulsionado nos anos 1960, sobretudo, depois do Festival de Viña del Mar em 1967, quando sua geração teve contato com a obra de Glauber Rocha. Com isso quis dizer que a renovação ocorrera antes, e fora, da UP e foi abortada pelo golpe. No exílio, percebeu a necessidade de se repensar a linguagem cinematográfica e a importância de se contar com um aparato industrial nesse tipo de produção, conforme existia na França onde estava exilado.

Raul Ruiz tornou-se, aliás, um cineasta de sucesso nesse país, tanto que teve um número inteiro da revista Cahiers du cinéma (n. 345 de 1983) dedicado à sua obra.

Revista Eletrônica da ANPHLAC, n.10, p. 83-125, jan./jun. 2011. http://revista.anphlac.org.br/index.php/revista 
Honra que, antes, fora concedida somente a um grupo seleto de cineastas, como Eisenstein, Godard, Pasolini e Welles. Seu trabalho foi também reconhecido pelos representantes de Araucaria que lhe dedicaram um "especial" na revista (MOUESCA e ORELLANA, 1983). Nessa homenagem, Ruiz foi descrito como um dos cineastas mais prolíficos (em dez anos, produziu 17 filmes) e interessantes do cinema chileno no exílio; comentou-se que suas histórias eram sinuosas, recheadas de jogo intelectual e ironia mordaz. Sua obra-prima, Las três coronas del marinero, foi especialmente elogiada. Mais uma vez, a revista Araucaria, mesmo mantida pelo PCCh, deu mostras de abertura política, ao homenagear Ruiz pela qualidade de seu trabalho independentemente de sua opinião sobre a esquerda chilena.

O cineasta Miguel Littin foi prestigiado em Araucaria em quatro ocasiões. Numa delas, através de entrevista feita por Isabel Parra (LITTIN, 1985), fez-se referência ao seu filme de maior sucesso até então, El chacal de norambuena, à sua participação na direção da Chile Films e ao exílio no México. Apresentando uma análise completamente oposta à de Raul Ruiz, Littin afirmou que, para ter o apoio da Chile Films, bastava apresentar um projeto coerente e começar a rodar. Relacionou, inclusive, o "boom" do cinema chileno de exílio, ou cinema de resistência, como preferia chamar, à existência dessa empresa cinematográfica, alegando que sem a sua ação não haveria tantos cineastas gabaritados em atividade naquele momento no exterior. Encerrou a entrevista, realizada em 1982, ou seja, no início da crise do modelo neoliberal, revelando sua intenção de regressar ao Chile para participar da luta contra a ditadura. A divergência de opinião entre os dois cineastas em relação à Chile Films evidencia a posição de cada um no campo intelectual: Littin alinhava-se àqueles que faziam de sua arte um meio de reflexão sobre as lutas sociais no Chile, denunciando a violência do poder e as mazelas sociais causadas pelo capitalismo; enquanto Ruiz demonstrou ser um intelectual cuja crítica aguda levava a um niilismo que via os problemas políticos e sociais como imanentes ao ser humano.

Na Araucaria número 32 de 1985, consta um relato de Miguel Littin sobre sua volta ao Chile na clandestinidade. Tinha o objetivo de fazer um filme que denunciasse a ditadura mostrando as muitas formas de resistência cotidiana do cidadão comum. O cineasta contou com o aparato clandestino do PCCh para rodar Acta General de Chile, que foi lançado, coincidentemente, no nono aniversário da Araucaria, de modo que a revista o homenageou nessa ocasião. Para Orellana, Littin mantinha sua postura 
engajada nas lutas do povo chileno, situando-se, assim, contra a corrente daqueles que pregavam o apolitismo intelectual (ORELLANA, 1986).

Na edição número 11 da revista foi publicado um debate sobre cinema chileno realizado no Festival de Cinema de Moscou em 1979, que contou com a participação dos cineastas Orlando Lübbert, Sebastián Alarcón, Eduardo Labarca, Cristián Valdés e Miguel Littin, com os escritores Jose Donoso e Jose Miguel Varas e com o crítico Jaime Barrios. Os temas discutidos foram: como denominar a produção artística feita por chilenos fora do Chile, o cinema e a construção das memórias da UP (do golpe, da repressão e do exílio), as vantagens e desvantagens do cinema épico coletivo, e as histórias mais intimistas. Todos os participantes comemoraram $\mathrm{o}$ fato de a cinematografia chilena ter sido a única na América Latina que poderia orgulhar-se do crescimento no exílio: entre 1973 e 1979, foram lançados mais de 50 filmes, segundo Orlando Lübbert (ALARCÓN, 1980).

Eventos como esse, que reuniu cineastas chilenos para trocar opiniões e ideias, eram uma exceção segundo a pesquisadora tcheca Zuzana Mirjan Pick (1983). Ela analisou um período de dez anos pós-golpe, e concluiu que, desde então, foram produzidos no exterior 155 filmes, somando os de longa, média e curta-metragem, e dentro do país, desde 1977, teriam sido produzidos mais de vinte. Para a autora, a ausência de trabalhos coletivos e de encontros entre cineastas chilenos (muitos deles não se conheciam) dificultava a avaliação do fenômeno em conjunto. Em seu ensaio, Pick mostrou que, logo após o golpe, os cineastas realizaram muitos documentários, grande parte com cenas ainda gravadas no Chile; lentamente começaram a produzir filmes de ficção, mas sempre com questionamentos sociais e políticos que poderiam ser associados ao futuro incerto do Chile.

É importante ressaltar que os cineastas chilenos não estiveram em muitos lugares além da Europa. Alguns deles produziram documentários sobre movimentos políticos nos países onde viveram exilados. Certo artigo publicado na Araucaria assinado simplesmente por R.A. (1988) noticia o trabalho dos cineastas chilenos Rodrigo Gonçalves sobre a construção do Estado Independente em Moçambique e Wolfgang Tirado sobre a revolução vitoriosa na Nicarágua.

Segundo entrevista do cineasta Cristián Sanchéz (1984), a produção no país foi quantitativamente inferior à do exterior: entre 1974 e 1984, foram realizados no Chile cinco filmes apenas. Jacqueline Mouesca (1988) publicou um ensaio que fazia um

Revista Eletrônica da ANPHLAC, n.10, p. 83-125, jan./jun. 2011. http://revista.anphlac.org.br/index.php/revista 
balanço da produção fílmica chilena durante o regime militar. Constatou que, no final dos anos 1970, com o crescimento da publicidade da televisão, surgiu a possibilidade de os cineastas se ligarem a produtoras de publicidade, pelas quais tiveram acesso a material importado que propiciou a produção de vídeos ficcionais. Mouesca fez referência ao documentário Chile, no invoco tu nombre en vano, feito pela equipe Cineojo, que conseguiu reunir em um mesmo projeto chilenos "de dentro" e exilados: os "de dentro" realizaram as filmagens, enquanto os "de fora" a edição e a distribuição do documentário. O trabalho da equipe Cine-ojo foi um exemplo bem-sucedido de articulação entre chilenos dos dois mundos, apesar de todos os perigos enfrentados pelos "de dentro" e das dificuldades enfrentadas pelos "de fora".

\section{Música}

Como a literatura, o teatro e o cinema, a música também teve seu espaço garantido na revista Araucaria. Durante o governo da Unidade Popular, foram os músicos aqueles que mais identificaram seu trabalho com a plataforma allendista. Em meados dos anos 1960, antes da campanha, surgiu o movimento da Nueva Canción Chilena (NCCh), que tinha como característica unir sonoridades folclóricas ao engajamento social, resultando, anos depois, em canções populares cantadas por milhares de pessoas nas marchas de apoio a Allende. Os mais famosos conjuntos da NCCh, o Inti-Illimani e o Quilapayún, estavam no exterior no momento do golpe, e foram proibidos de retornar. O cancionista Víctor Jara estava no país e iria apresentar-se num ato convocado por Salvador Allende na Universidade Técnica do Estado, quando ali foi preso e levado ao Estádio Nacional, de onde não sairia vivo. Com o golpe a $\mathrm{NCCh}^{16}$ foi proibida no Chile e, no exílio, começou uma nova fase na qual, paralelamente aos trabalhos de solidariedade, iniciaram-se novas experiências musicais.

Logo na segunda edição da revista Araucaria, a seção Capitulos de la Cultura Chilena foi dedicada à música. A capa dessa edição é de autoria de Roberto Matta e faz

$16 \mathrm{Na}$ revista Araucaria participantes da Nueva Canción Chilena estiveram presentes como colaboradores, através de entrevistas e artigos. Osvaldo Rodriguez Musso (cancionista conhecido como El Guitano Rodriguez) publicou artigos e entrevistas, totalizando 22 participações na Araucaria. Isabel Parra publicou duas entrevistas: a primeira com o compositor cubano Sílvio Rodriguéz, na Araucaria 16, e depois com o cineasta Miguel Littin, na Araucaria 21; também o seu El libro mayor de Violeta Parra foi editado pelas ediciones Michay, editora da revista. Foram ainda publicados: uma entrevista com o conjunto Inti-Illimani; uma crônica sobre o Quilapayún e uma poesia de seu diretor artístico Eduardo Carrasco; uma entrevista e um artigo de Angel Parra; e seis textos e uma entrevista com Patrício Manns.

Revista Eletrônica da ANPHLAC, n.10, p. 83-125, jan./jun. 2011. http://revista.anphlac.org.br/index.php/revista 
referência direta ao assassinato de Víctor Jara: um homem amarrado sobre o violão com as mãos amputadas (de acordo com testemunhas que presenciaram a tortura e morte do cantautor chileno). O desenho de Matta captou e transmitiu, em poucos traços, a dramaticidade daquele momento, através do corpo violentamente esticado, deformado pela dor, sobre um vilão (guitarra em espanhol), instrumento tocado por Víctor.

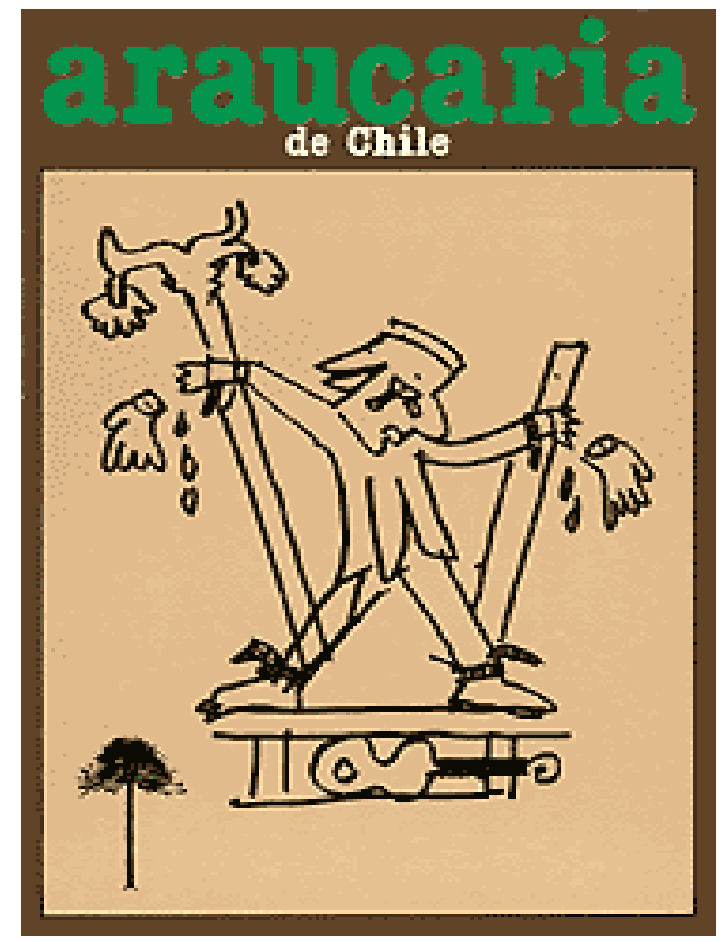

Ilustração 3: Capa da Araucaria $n^{\circ} 2$ autoria Roberto Matta. Fonte: memoriachilena.cl

Luis Bocaz afirmou, na abertura do "especial", que a música chilena adquirira no exterior grande dimensão depois do golpe de 1973, momento em que seus principais expoentes passaram a ser considerados símbolos da resistência à ditadura. Ainda nessa seção foi publicado um debate sobre música chilena na forma de questionário respondido por diversos músicos (BIANCHI; BOCAZ; ORELLANA, 1978). As questões foram elaboradas pelos membros do comitê editorial Soledad Bianchi e Luis Bocaz, e a montagem dos textos coube a Carlos Orellana. A identificação da publicação com as canções engajadas é nítida: das 22 perguntas enviadas, 12 diziam respeito à relação entre música e política. Por essa razão, o músico Hans Stein enviou uma carta avisando que não responderia ao questionário que estava direcionado aos participantes da NCCh, e, além disso, considerava as perguntas demasiado "subjetivas", o que impossibilitava um debate "objetivo" sobre a música chilena. O fato de tal carta ter sido 
publicada indica a preocupação dos editores em mostrar que a revista estava aberta aos diversos posicionamentos.

Quando perguntados sobre as origens da NCCh e sobre as influências de músicos nacionais em seus trabalhos, todos os entrevistados fizeram referência, em primeiro lugar, a Violeta Parra, e depois a Víctor Jara. A atuação de Violeta Parra como compositora e intérprete de canções folclóricas campesinas, fora sua dedicação à pesquisa percorrendo o Chile com um gravador, representou uma influência decisiva na $\mathrm{NCCh}$; foi também a primeira compositora a abordar temas políticos e sociais, além de denunciar injustiças e formas de violência, em canções como ¿Qué diria el santo padre? e La carta. Em uníssono, todos que fizeram referência a Violeta, lhe atribuem um caráter forte e uma capacidade criadora incomparável, interrompida apenas por suas próprias angústias e uma bala em 1967. Contudo o "Parral”, donde saíra Violeta, já havia dado frutos como o "antipoeta" Nicanor Parra e continuaria a dar outros como seus filhos Isabel e Angel.

Víctor Jara, exemplo de artista engajado, ator, diretor, compositor e cantor reconhecido internacionalmente, foi mencionado na Araucaria em diversas entrevistas e testemunhos. Todos os autores enfatizaram a genialidade artística e o compromisso político de Jara, que foi uma das primeiras vítimas da ditadura.

A Araucaria abriu suas páginas também ao conjunto Inti-Illimani, exilado na Itália. Cabe mencionar duas entrevistas publicadas nos número 42 e 43 , respectivamente. Nelas, os membros do conjunto revelaram que nunca se dispuseram a fazer canções exclusivamente políticas, compuseram-nas nos últimos tempos da UP devido à radicalização política. Explicaram que suas opções políticas sempre estiveram atreladas ao trabalho artístico, sendo esse aspecto o mais importante. Reconheceram que canções como El pueblo unido ainda emocionavam, contudo acreditavam que o excesso de politização da arte já havia saturado seu público, principalmente em Roma, onde estavam exilados (RUIZ; CIFUENTES, 1988).

Outro importante conjunto da NCCh, exilado em Paris, e outrora declaradamente engajado, era o Quilapayún, dirigido pelo filósofo Eduardo Carrasco. Diferentemente do Inti-Illimani, o grupo assumiu produzir "canções contingentes", porém não acreditava que isso deveria se sobrepor à qualidade artística (CARRASCO, 2000). Em 11 de setembro de 1973, em turnê pela Europa, foram proibidos de regressar ao país. O Quilapayún também esteve presente em Araucaria, sendo alvo de uma polêmica que 
vale mencionar. Tudo começou com uma crônica de Orellana (1981), que discorria sobre os diferentes significados que as canções do grupo Quilapayún adquiriram no desenrolar da luta política no Chile e em sua trajetória pessoal no exílio. A crônica foi tomada como ofensiva pelos membros do conjunto, pois foi interpretada como uma cobrança de engajamento. Responderam, então, com uma carta publicada na seção $D e$ los lectores da revista número 18, assinada por Hugo Lagos, que declarava que a arte não deveria ser avaliada com os parâmetros temporalmente estreitos da política (LAGOS, 1982). Outras polêmicas ocorreram entre representantes da revista e do grupo Quilapayún; acredito que as divergências sobre concepções de cultura e política explicam a esparsa presença do grupo nas páginas da Araucaria, apesar de se tratar de um dos expoentes na música chilena com maior projeção durante o exílio. ${ }^{17}$

No início da ditadura, as músicas da "Nova Canção Chilena" foram, pois, proibidas e seus expoentes exilados. Contudo, depois de 1974, surgiu no país o Canto Nuevo, que foi objeto de análise de Bernardo Subercaseaux. O crítico e ensaísta, professor em Washington, analisou o fenômeno entre 1973 e 1980, na Araucaria número 12 (SUBERCASEAUX, 1980). Para o autor, as canções do Canto Nuevo tinham mais apelo à unidade nacional que à mobilização contra a ditadura. Além disso, havia maior preocupação em dialogar com sonoridades diversas - do pop à música erudita -, o que representava um novo cenário musical em que se firmou o selo Alerce e houve ainda o ressurgimento das peñas. Segundo o autor, gradualmente os compositores voltaram a escrever trabalhos originais, procurando evitar problemas com a censura. A partir de 1978, o retorno de alguns artistas, como Tita Parra (neta de Violeta) e o conjunto Los Blops, também acrescentou novos ingredientes ao cenário musical: era o momento de buscar inspiração tanto em Rolling Stones como em Violeta Parra e, ao mesmo tempo, de estudar instrumentos clássicos. Valorizavam-se as novidades, enfatizando sempre que se tratava de uma estética e de letras que, no fundo, apelavam à unidade.

Além do Canto Nuevo, teve espaço em Araucaria a música erudita: Gustavo Becerra, Claudio Arrau e Luis Advis foram alguns dos artistas chilenos que fizeram

\footnotetext{
17 Por ocasião do falecimento do poeta Enrique Lihn, Orellana escreveu um obituário no-qualem que narrou uma apaixonada defesa da obra do poeta durante uma discussão com um "músico filósofo" ocorrida nas proximidades de Barcelona em 1978. O músico filósofo teria acusado Lihn de ser pequenoburguês e anticomunista. Depois, Orellana denunciou que quem havia dado voltas em suas paixões (e não posições) político-ideológicas teria sido o músico. Em sua biografia, de modo mais atenuado, Orellana descreveu a mesma discussão, desta vez, nomeando Eduardo Carrasco diretor do Quilapayún, como seu interlocutor. (ORELLANA, 1988, p. 125-129; ORELLANA, 2002).
}

Revista Eletrônica da ANPHLAC, n.10, p. 83-125, jan./jun. 2011. http://revista.anphlac.org.br/index.php/revista 
sucesso no exterior e marcaram presença no periódico através de entrevistas. Já o conhecido músico Sergio Ortega, que, embora militante comunista, estivera ligado durante muito tempo ao grupo Quilapayún, foi pouco prestigiado.

Observa-se que, nesse novo contexto musical, ganhou importância a defesa da integração entre música erudita, popular/folclórica e a mídia. O especial da revista número 2 publicou uma entrevista com o compositor Gustavo Becerra (1978), que afirmou ser impossível compreender a imensa circulação cultural da segunda metade do século XX sem mencionar a verdadeira revolução imposta pela presença dos meios de comunicação de massas. Argumentou que a indústria fonográfica conquistou o poder de selecionar e classificar os ritmos musicais de acordo com sua lucratividade. Becerra acrescentou que não se poderiam entender os três grandes conjuntos em que estava dividida a música chilena (erudita, popular e folclórica), senão a partir de relações recíprocas, pois apesar das diferenças, o trânsito entre eles e o conhecimento mútuo das obras enriqueceriam muito a cultura chilena. Tomou como exemplo a circulação cultural entre o erudito e o popular presente no trabalho de Víctor Jara, que uniu a reflexão musical e a produção popular folclórica.

O pianista chileno Claudio Arrau foi lembrado em duas ocasiões na revista Araucaria (TEITELBOIM, 1983; MANSILLA, 1988). Nelas se procurou mostrar que, além de um prodígio do piano, se tratava de um homem capaz de demonstrar indignação frente à ditadura ao realizar concertos beneficentes para a Vicaria de Solidariedad, embora sempre mantivesse muita discrição quanto às suas opiniões políticas. Acabou aceitando a cidadania estadunidense depois do golpe militar, pois já vivia nos Estados Unidos havia muitos anos.

\section{Artes Plásticas}

Logo no número de lançamento da revista, a seção Capítulos de la Cultura Chilena dedicou-se a La Plastica. Essa primazia se deve ao fato de que centenas de artistas plásticos do mundo inteiro manifestaram solidariedade ao governo da Unidade Popular doando obras para o Museu de Solidariedad. Idealizado pelo crítico de arte espanhol José Maria Moreno Galván, que encorajado pelo pintor José Balmés levou a ideia para Allende que a acolheu, o museu foi inaugurado em 1972, e fechado logo após o golpe. Contudo, a nova situação de repressão e horror intensificou a solidariedade dos

Revista Eletrônica da ANPHLAC, n.10, p. 83-125, jan./jun. 2011. http://revista.anphlac.org.br/index.php/revista 
artistas com a causa democrática chilena. Surgiu, então, o Museu de Resistencia Salvador Allende, constituído por uma coleção de obras em exposição itinerante pelo exílio, cuja ideia era demonstrar a solidariedade na luta contra a ditadura (CATÁLOGO, 2007). Cabe chamar a atenção para o fato de que, mais uma vez, nesse aspecto da cultura, a parceria entre a arte e a política foi evidente.

O referido especial da revista sobre La plastica trouxe também uma entrevista com José Balmés realizada por Luis Bocaz (BALMES, 1978), cujo tema central foi o engajamento dos artistas plásticos chilenos. Balmés avaliou que o clima de agitação começou, na América Latina, nos anos 1950, tendo como referência o muralismo mexicano caracterizado como pintura política; a década que se abriu com a publicação de Canto General de Pablo Neruda e se encerrou com a Revolução Cubana formou uma geração de artistas cujos trabalhos estavam em profunda sintonia com as causas populares. Balmés afirmou que, no período da UP, não houve nenhum tipo de dirigismo artístico, e que sua arte era uma representação do humano, com todas as suas consequências, inclusive as lutas políticas e sociais. Ao final, Balmés comentou sobre a força da solidariedade com o Chile demonstrada com a inauguração em 1977 do Museu de Resistencia Salvador Allende em Nancy, prosseguindo com manifestações artísticas em Avignon, Reins, Barcelona e Madri, e a reorganização das brigadas muralistas no exílio, das quais participaram artistas chilenos reconhecidos internacionalmente, como Gracia Barros, Guillermo Nuñez, José Martínez, entre outros.

Na mesma seção Capítulos de la Cultura Chilena sobre artes plásticas, há um depoimento do artista plástico Guillermo Nuñez (1978), que narrou suas experiências nos campos de concentração da ditadura, afirmando que, desde então, resolveu fazer de sua pintura um testemunho para as gerações futuras das atrocidades ocorridas em seu país. Ainda nesse espaço foi publicado um trecho do discurso de Rafael Agustín Gumucio proferido na ocasião de abertura da exposição de solidariedade em Reims (abril de 1977), seguido da listagem de todos os participantes. ${ }^{18}$ No final da seção foi reproduzido um cartaz da exposição El pueblo tiene arte con Allende, que aconteceu simultaneamente em mais de 80 locais por todo o Chile, com obras de mais de 30 artistas que apoiaram a UP em 1972.

18 Constava ainda uma lista com todos os responsáveis pelo Museu de Resistência Salvador Allende, presidido pelo brasileiro Mario Pedrosa, auxiliado pelos secretários Miria Contreras, Miguel Rojas-Mix, José Balmés, Pedro Miras e Jacques Leenhard. O comitê para a França incluiu nomes de peso como Julio Cortázar, Luis Althusser, Roland Barthes, Regis Debray e Alain Touraine. Foram listados também os nomes de todos os artistas que doaram obras ao museu.

Revista Eletrônica da ANPHLAC, n.10, p. 83-125, jan./jun. 2011. http://revista.anphlac.org.br/index.php/revista 


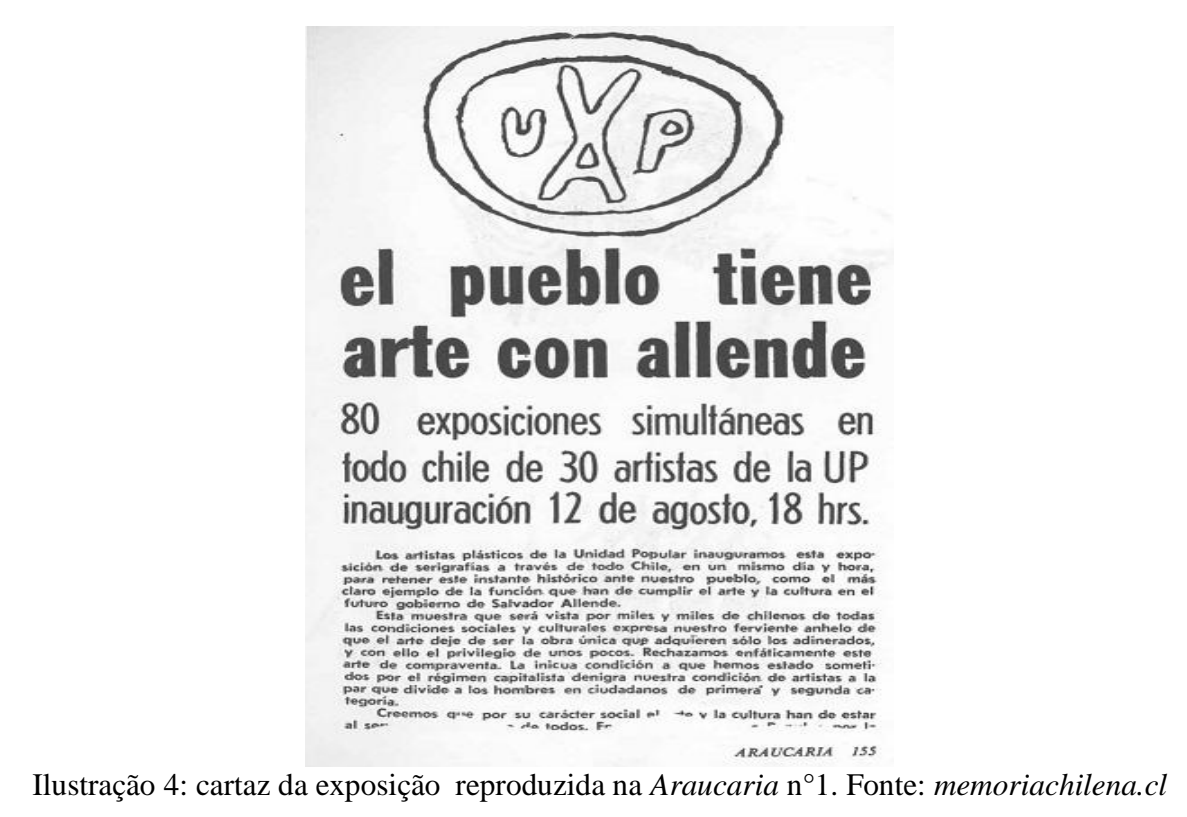

Apesar de proibido de reingressar em seu país, José Balmés conseguiu expor suas obras no Chile. No final de 1979, Luis Alberto Mansilla noticiou em Araucaria a abertura de uma exposição de Balmés e outros exilados, Gracia Barros e Guillermo Nuñez, na galeria Imagen em Santiago. A notícia prova que, mesmo com a proibição da volta ao país, a Junta Militar fazia "vistas grossas" em relação à exposição de obras de artistas renomados.

No início dos anos 80, alguns artistas retornaram, enfim, ao país Entre eles, o próprio Jose Balmés e Nemésio Antunes, que, em entrevistas publicadas em Araucaria, valorizaram a experiência do exílio como possibilidade de enriquecimento cultural, mas lamentaram o quadro de mercantilização da sociedade, que atingira também as artes (PIZARRO ILLANES, 1982; ANTUNES, 1982).

Um dos artistas plásticos mais prestigiados pela revista foi Roberto Matta, que teve duas longas entrevistas publicadas. Na primeira, ainda no número de estreia da Araucaria, discorreu sobre sua trajetória artística e a situação política do Chile, lembrando que, apesar de viver no exterior havia vários anos, teve sua cidadania cassada pelos golpistas em 1975. Matta definiu-se não como um artista político, mas como um artista revolucionário, no sentido amplo do termo (MATTA, 1978). Na segunda entrevista, expressou seus sentimentos sobre a América Latina, suas novas perspectivas de trabalho e como o contato com artistas como Mistral, Neruda e Garcia Lorca influiu em suas obras (MATTA, 1980).

As brigadas muralistas - importante manifestação da intensa relação entre arte

Revista Eletrônica da ANPHLAC, n.10, p. 83-125, jan./jun. 2011. http://revista.anphlac.org.br/index.php/revista 
e política nos anos 1960 e 1970 - foram lembradas pela Araucária. Carlos H. Leon (1983) analisou o fenômeno muralista chileno a partir das referências estéticas do muralismo mexicano, do que chamou surrealismo de Roberto Matta e da ideia de herói coletivo, cuja fonte seriam os filmes de Eisenstein. $\mathrm{O}$ autor considerou que os murais tinham como função mostrar o povo como sujeito do processo de transformação social, constituindo uma obra de arte criada pelo e para o povo e também um meio de propaganda e afirmação ideológica. Ainda sobre o muralismo chileno, a revista publicou o testemunho de Patrício Cleary (1988) acerca de seu surgimento durante a campanha presidencial de Allende de 1964 e o vigor alcançado na campanha de 1970.

A atenção dada às artes plásticas chilenas pela Araucaria estava até mesmo em sua parte gráfica. O responsável por essa parte, Fernando Orellana, filho de Carlos Orellana, era estudante da Universidade Técnica na ocasião do golpe, e como todos os que estavam na instituição foi preso. No exílio estudou fotografia com Rafael Vega Querat, e, quando retornou ao Chile, fez uma série de fotos reunidas em seu livro Chileno de Chile en Chile publicado pelas ediciones del Meridion (editora organizada pelo comitê editorial de Araucaria).

A revista Araucaria apresentou o que considerou o melhor da criação plástica chilena em suas capas (única parte colorida da revista) e nas ilustrações (em preto e branco devido à escassez de recursos) publicadas em suas páginas. Como já mencionado, os artistas, por mais renomados que fossem, não eram remunerados por suas colaborações. Essa era uma forma de demonstrar o apoio a uma revista cuja principal causa era divulgar a cultura chilena, colocando em contato toda uma geração de criadores culturais que viviam no exílio.

A parte gráfica da revista demonstrou a abertura da publicação para as mais diversas tendências artísticas, sem necessariamente tratar-se de uma arte engajada, militante ou didática, o que, em certos casos, causou a irritação de alguns membros do PCCh. ${ }^{19} \mathrm{O}$ contraste das duas capas a seguir evidencia a diversidade de tendências artísticas representadas na publicação:

19 Como mostra o episódio de uma carta dirigida ao Secretário Geral do PCCh Luis Corvalán, que tecia severas críticas à revista em relação ao seu conteúdo (tachado de elitista) e suas ilustrações "que quando não incompreensíveis eram pornográficas”. Cf. DE FRANKFURD, Meno. De los lectores. Araucaria de Chile. Madrid: Ediciones Michay, n. 14, p. 6-7, $2^{\circ}$ trimestre 1981.

Revista Eletrônica da ANPHLAC, n.10, p. 83-125, jan./jun. 2011. http://revista.anphlac.org.br/index.php/revista 


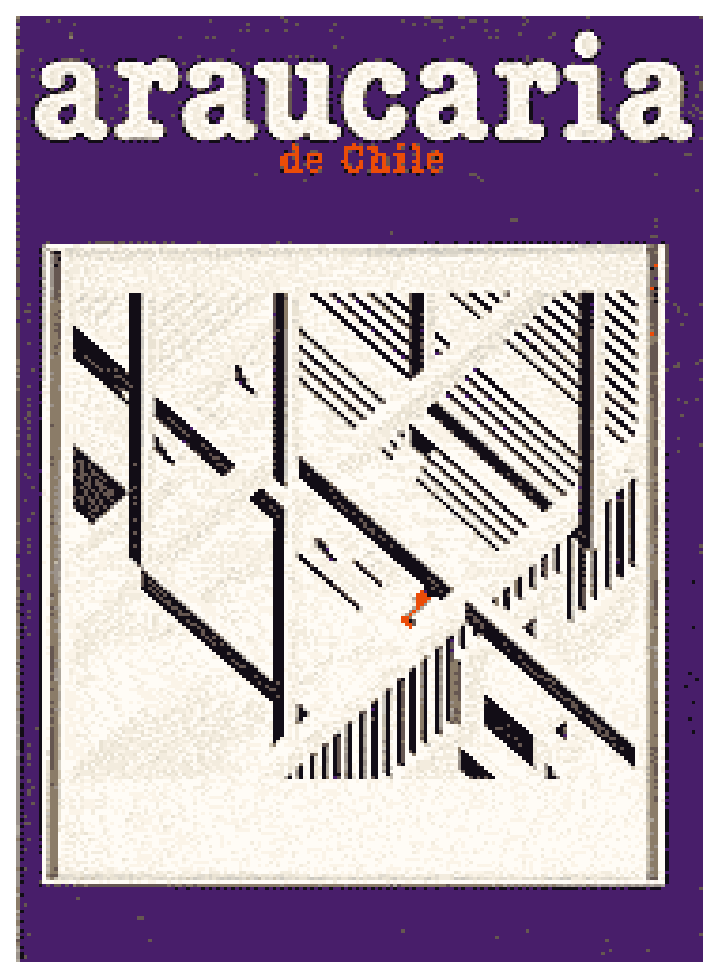

Ilustração 5: capa da Araucaria $n$ ○8 reprodução de quadro abstrato de Rafael Vega Querat. Fonte: memoriachilena.cl

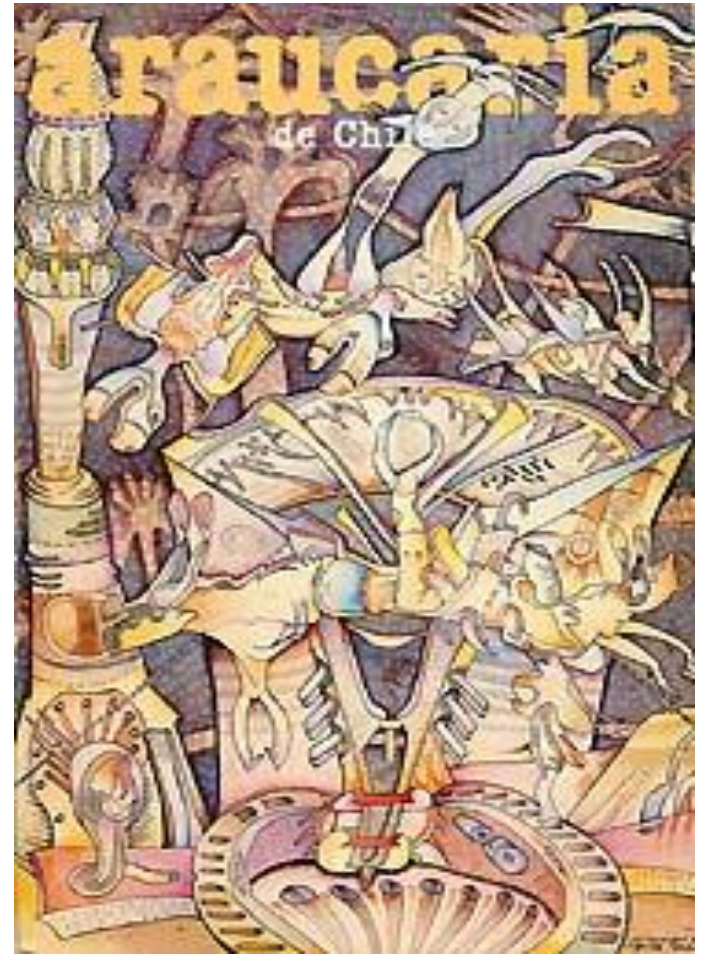

Ilustração 6: capa da Araucaria $n^{\circ} 17$ reprodução de uma pintura de Mario Múrua. Fonte:

memoriachilena.cl

A capa da Araucaria n. 8 de autoria de Rafael Vega Querat emprega a linguagem geométrico-construtiva, através da construção de um espaço dentro de outro espaço, utilizando muitos ângulos retos. Nessa obra, figura/ fundo preto/ branco se alternam confundido o olhar. Há também um detalhe vermelho no meio que tem a finalidade de equilibrar a obra, que é, ao mesmo tempo, precisa e leve. Um estilo completamente diferente apresenta a capa da Araucaria n. 17, com características surrealistas presentes nas figuras que não são imediatamente associadas a nada conhecido; o espaço parece ganhar vida com essas figuras imaginárias, criando uma atmosfera onírica.

Claro que havia também capas engajadas, com referências à miséria a qual a política econômica neoliberal mergulhara a maior parte da população, à violência utilizada pela Junta Militar para impor seu mando, e à resistência dos que permaneceram no país. As capas seguintes exemplificam a presença da arte engajada na revista.

Revista Eletrônica da ANPHLAC, n.10, p. 83-125, jan./jun. 2011.

http://revista.anphlac.org.br/index.php/revista 


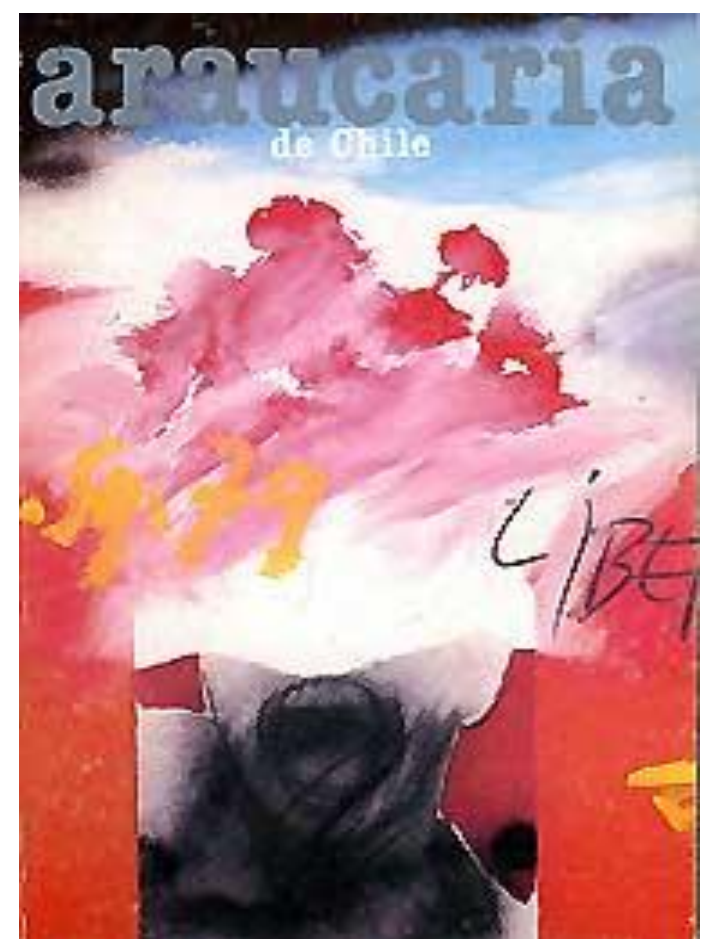

Ilustração 7: capa da Araucaria ${ }^{\circ} 12$ pintura de Jose Balmes. Fonte: www.memoriachilena.cl

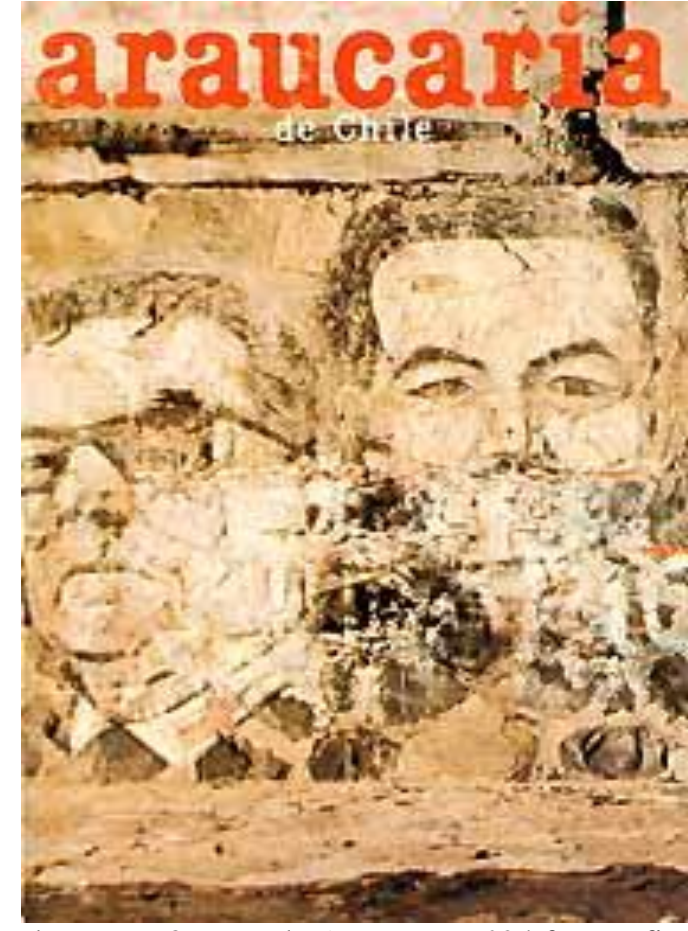

Ilustração 8: capa da Araucaria ${ }^{\circ} 24$ fotografia de Rudolf Lequin. Fonte: www.memoriachilena.cl

O trabalho de José Balmés, publicado na capa da Araucaria n. 12, apresenta características abstracionistas: na obscuridade, na parte de baixo, há uma boca gritando Libertad, escrita ao lado direito, com a indicação do ano 1979, ao esquerdo; e, na parte superior, aparecem as cores da bandeira chilena pintadas livremente.

A capa da revista n. 24 é uma fotografia do muro norte do rio Mapocho tirada em 1979 pelo bioquímico holandês Rudolf Lequin. A imagem mostra que ainda resistia, durante o governo da Unidade Popular, um mural pintado no qual figuram os rostos de Allende, à esquerda, e provavelmente do revolucionário cubano José Martí, à direita.

Revista Eletrônica da ANPHLAC, n.10, p. 83-125, jan./jun. 2011. http://revista.anphlac.org.br/index.php/revista 


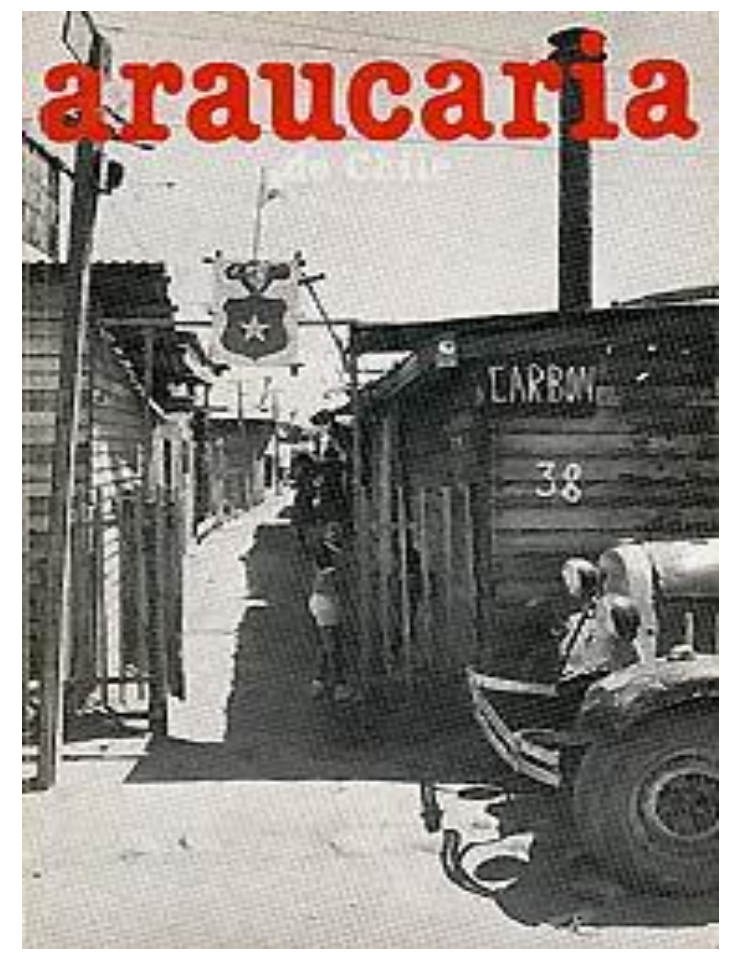

Ilustração 9: capa da Araucaria $\mathrm{n}^{\circ} 29$ fotografia de Fernando Orellana. Fonte: $w w w . m e m o r i a c h i l e n a . c l$

Na nona ilustração — a capa da Araucaria n. 29 —, vê-se uma foto de Fernando Orellana retratando uma población, cujos moradores encabeçavam as jornadas de protestos do início dos anos 1980 (tema de muitos textos desse número) e eram, por isso, os principais alvos da repressão. Nessa capa é marcante o contraste entre luz e sombra, expresso pelo foco do fotógrafo que destacou o caminho iluminado entre as casas escuras.

Essas capas são uma amostra da variedade das ilustrações da revista Araucaria. Como se pode verificar, de uma imagem "abstrata" a outra mais "engajada", diversas tendências artísticas encontraram espaço na publicação, que, a cada número, contou com cerca de três artistas, totalizando a colaboração de mais de uma centena deles na confecção das ilustrações.

A referência exaustiva sobre as diversas manifestações artísticas chilenas apresentadas e discutidas na Araucaria teve o intuito de mostrar que, além de veículo de disseminação dos produtores e produtos culturais, a própria revista pode ser entendida como um importante produto cultural realizado por chilenos, que, no exílio, não só contribuíram para a divulgação de intelectuais e artistas, mas também se tornaram mediadores culturais num momento em que cultura e política se mesclaram em função de uma conjuntura específica - a ditadura militar.

Revista Eletrônica da ANPHLAC, n.10, p. 83-125, jan./jun. 2011. http://revista.anphlac.org.br/index.php/revista 


\section{Considerações Finais}

Os membros do comitê editorial de Araucaria conseguiram atingir os objetivos explicitados no primeiro número da revista, ou seja, atuar como elo entre a produção cultural "de dentro" e "de fora" do país e, assim, colaborar para manter vivos a cultura chilena e o sentimento de solidariedade e luta contra a ditadura.

A "contrarreforma" universitária foi denunciada pela revista como um exemplo gritante do que estava ocorrendo na sociedade como um todo: a transformação de direitos em mercadorias, e, por extensão, os chilenos passaram de cidadãos a consumidores. Desde a Frente Popular nos anos 1930, mas, principalmente, durante os anos da Unidade Popular (1970-1973), o sistema universitário era o instrumento do Estado para atuar como mecenas das manifestações culturais e também para incentivar a pesquisa científica visando o benefício social. Ao desmontar e privatizar o sistema universitário, a ditadura jogou produtores culturais e pesquisadores nas mãos invisíveis, volúveis e duras do mercado. O Estado estava a serviço das empresas privadas, e não mais da sociedade.

As diversas expressões artísticas abordadas na revista (literatura, teatro, cinema, música e artes plásticas) mostram que não foi possível amordaçar um país inteiro. Ainda que de modo atomizado, certas manifestações artísticas, como o teatro, pequenos locais de espetáculos como as peñas, e a produção literária, continuaram mesmo sob as botas dos militares. A exceção ficava por conta daquelas manifestações que precisavam de vultuosos recursos, como o cinema, ou cuja realização acarretava grandes concentrações, como os festivais de música. Essa constatação do que ocorreu dentro do país foi, indiscutivelmente, uma grata surpresa apontada pela revista Araucaria.

$\mathrm{O}$ tom testemunhal esteve presente em todas as manifestações artísticas elencadas pela Araucária, tanto na produção desenvolvida dentro do Chile quanto no exílio. Esse aspecto é o que torna tal período especialmente rico em fontes variadas que transitam entre a arte e a política. Em suma, considero válido e pertinente afirmar que a existência da revista possibilitou um intenso, e muito profícuo, debate sobre a cultura e a política chilenas, apesar da situação extremamente adversa.

Revista Eletrônica da ANPHLAC, n.10, p. 83-125, jan./jun. 2011. http://revista.anphlac.org.br/index.php/revista 


\section{Fontes}

AC. De los lectores. Araucaria de Chile, Madrid: Ediciones Michay, n. 28, p. 7, $4^{\circ}$ trimestre 1984.

ADVIS, Luis. Dulce patria americana. Temas. Araucaria de Chile, Madrid: Ediciones Michay, n. 44, p. 159-166, $4^{\circ}$ trimestre 1988. (Entrevista concedida a Marcelo Decap). ALARCÓN, Luis. Luis Alarcón: Actuar a lo penquista. Capítulos de la cultura chilena. Araucaria de Chile, Madrid: Ediciones Michay, n. 31, p. 143-153, 3 trimestre 1985. (Entrevista concedida a Carlos Orellana e Luis Bocaz).

ALARCON, Sebastián et al. Orientanción y perspectivas de cine chileno. Mesa redonda con Sebastián Alarcón, Jaime Barrios, José Donoso, Eduardo Labbarca, Miguel Littin, Orlando Lübbert, Christián Valdés e José Miguel Varas. Capítulos de la cultura chilena: el cine. Araucaria de Chile, Madrid: Ediciones Michay, n. 11, p. 119-135, $3^{\circ}$ trimestre 1980.

ALCIDES JOFRÉ, Manuel. El ojo del huracán: un coloquio de literatura chilena. Exámenes. Araucaria de Chile, Madrid: Ediciones Michay, n. 29, p. 114-116, $1^{\circ}$ trimestre 1985.

Novela chilena del interior. Temas: la narrativa chilena post-golpe. Araucaria de Chile, Madrid: Ediciones Michay, n. 39, p. 136-156, $3^{\circ}$ trimestre 1987.

ANTUNES, Nemesio. Nos están borrando el Chile nuestro. Temas. Araucaria de Chile, Madrid: Ediciones Michay, n. 17, p. 149-150, $1^{\circ}$ trimestre 1982.

Araucaria de Chile en Chile. Araucaria de Chile $\mathrm{n}^{\circ} 44$. Madrid: Ediciones Michay, $4^{\circ}$ trimestre 1988

BALMÉS, José. El desafio de la pintura politica. (Conversación con José Balmés).

Capítulos de la cultura chilena. Araucaria de Chile, Madrid: Peralta Ediciones, n. 1, p. 106-140, $1^{\circ}$ trimestre 1978. (Entrevista concedida a Luis Bocaz).

BECERRA, Gustavo. Musica Chilena y identidad cultural. Capítulos de la cultura chilena. Araucaria de Chile, Madrid: Peralta Ediciones, n. 2, p. 97-109, $2^{\circ}$ trimestre 1978. (Entrevista concedida a Luis Bocaz).

BELLET, J. Cruzando la cordilleira con el poeta. Araucaria de Chile, Madrid: Ediciones Michay, n. 47/48, p. 186-202, 4 trimestre 1989.

BIANCHI, Soledad; LOYOLA, Hernan. Poesia chilena: la resistencia y el exilio. Los

Revista Eletrônica da ANPHLAC, n.10, p. 83-125, jan./jun. 2011. http://revista.anphlac.org.br/index.php/revista 
libros. Araucaria de Chile, Madrid: Ediciones Michay, n. 7, p. 193-204, $3^{\circ}$ trimestre 1979.

Bocaz e Orellana: discusión sobre la musica chilena. Participan: Hugo Arevalo,

Eduardo Carrasco (Quilapayún), Patrício Castillo, Charo Cofré, Miguel Angel

Cherubito, Eulogio Dávalos, Fernando Garcia, Inti-Illimani, Patrício Manns, Sergio

Ortega, Angel Parra, Isabel Parra, Osvaldo Rodriguez, Daniel Salinas, Hans Stein,

Trabunche. Questinonario elaborado por: Soledad Bianchi y Luis Bocaz. Seleción y montaje Carlos Orellana. Capítulos de la cultura chilena. Araucaria de Chile, Madrid: Ediciones Michay, n. 2, p. 111-173, $2^{\circ}$ trimestre 1978.

BRAVO-ELIOZONDO, Pedro. El teatro obrero en Chile: algunos antecedentes. Temas. Araucaria de Chile, Madrid: Ediciones Michay, n. 17, p. 99-106, $1^{\circ}$ trimestre 1982. El teatro en Chile en la decada del 70: algunos antecedentes. Temas. Araucaria de Chile, Madrid: Ediciones Michay, n. 13, p. 127-135, $1^{\circ}$ trimestre 1981. CALDERÓN, Alfonso. La cultura chilena (1973-1983): las vantajas de la mala fe. Exámenes. Araucaria de Chile, Madrid: Ediciones Michay, n. 24, p. 67-75, $3^{\circ}$ trimestre 1983.

CASTRO, Oscar. El teatro en los campos de concentración. Capítulos de la cultura chilena. Araucaria de Chile, Madrid: Ediciones Michay, n. 6, p. 115-147, $2^{\circ}$ trimestre 1979. (Entrevista concedida a Ariel Dorfman).

CATÁLOGO DO MUSEU DE SOLIDARIEDADE SALVADOR ALLENDE: estéticas, sonhos e utopias dos artistas do mundo pela liberdade. São Paulo: Associação Museu Afro Brasil/ Imprensa Oficial do Estado, 2007.

CERDA, Carlos. Realismo y configuración mimetica de la realidad en dos novelas chilenas. Temas: la narrativa chilena post-golpe. Araucaria de Chile, Madrid: Ediciones Michay, n. 39, p. 129-135, $3^{\circ}$ trimestre 1987.

CIFUENTES, Luis. Los años de la esperanza (en torno de una conversación con IntiIllimani).Temas. Araucaria de Chile, Madrid: Ediciones Michay, n. 43, p. 145-158, $3^{\circ}$ trimestre 1988.

CLEARY, Patricio. Como nació la pintura mural politica en Chile. Cronica. Araucaria de Chile, Madrid: Ediciones Michay, n. 42, p. 193-195, $2^{\circ}$ trimestre 1988.

CODDOU, Marcelo. Poesia chilena en el exilio. Temas. Araucaria de Chile, Madrid: Ediciones Michay, n. 14, p. 99-109, $2^{\circ}$ trimestre 1981.

CONCHA, Jaime.Testimonios de la lucha anti-fascista. Temas. Araucaria de Chile,

Revista Eletrônica da ANPHLAC, n.10, p. 83-125, jan./jun. 2011. http://revista.anphlac.org.br/index.php/revista 
Madrid: Ediciones Michay, n. 4, p. 129-147, 4 trimestre 1978.

Tres novelas chilenas posteriores a 73.Temas: la narrativa chilena post-golpe.

Araucaria de Chile, Madrid: Ediciones Michay, n. 39, p. 118-128, $3^{\circ}$ trimestre 1987.

CORVALÁn, Luis. De lo vivido y lo peleado. Santiago: LOM, 1997. p. 248.

DIAZ, Jorge. El desarraigo voluntario de Jorge Díaz. Capítulos de la cultura chilena.

Araucaria de Chile, Madrid: Ediciones Michay, n. 30, p. 133-146, $2^{\circ}$ trimestre 1985.

(Entrevista concedida a Eduardo Guerreiro).

DONOSO, José. Acercamiento a casa del campo. Temas. Araucaria de Chile, Madrid:

Ediciones Michay, n. 6, p. 69-74, $2^{\circ}$ trimestre 1979. (Entrevista concedida a Osvaldo

Rodríguez).

DORFMAN, Ariel. El Estado chileno actual y los intelectuales: acercamiento preliminar de algunos problemas impostergables. Exámenes. Araucaria de Chile, Madrid:

Ediciones Michay, n. 10, p. 35-51, $2^{\circ}$ trimestre 1980.

EDITORIAL. Araucaria de Chile, Madrid: Ediciones Michay, n. 1, p. 6-7, $1^{\circ}$ trimestre 1978.

EPPLE, Juan Armando. Notas sobre la cueca larga de Violeta Parra. Araucaria de Chile, Madrid: Ediciones Michay, n. 5, p. 187-197, $1^{\circ}$ trimestre 1979.

FRIKE, Maria Teresa; PARADA, Roberto; SOTOCONIL, Rúben. El teatro

experimental. Captulos de la cultura chilena. Araucaria de Chile, Madrid: Ediciones

Michay, n. 6, p. 103-114, $2^{\circ}$ trimestre 1979. (Entrevista concedida a Ramon de

Guzman).

GONZALEZ VERGARA, Ruth; RAJEVIC, Pia. Violeta Parra: testimonio de un patrimonio mayor. Araucaria de Chile, Madrid: Ediciones Michay, n. 32, p. 193-199, $4^{\circ}$ trimestre 1985.

GUERREIRO, Samuel. Luces nuevas en la cultura chilena. Temas. Araucaria de Chile, Madrid: Ediciones Michay, n. 6, p. 77-85, $2^{\circ}$ trimestre 1979.

GUZMAN, Patricio. Hacer la memoria de Chile. Capítulos de la cultura chilena.

Araucaria de Chile, Madrid: Ediciones Michay, n. 11, p. 137-143, 3 trimestre 1980.

(Entrevista concedida a Pedro Sempere).

JARA, Joan. Las manos de Víctor Jara. Capítulos de la cultura chilena: la musica.

Araucaria de Chile, Madrid: Ediciones Michay, n. 2, p. 176-180, $2^{\circ}$ trimestre 1978.

Víctor Jara: un canto inconcluso. Los heroes no están cansados. Araucaria de

Chile, Madrid: Ediciones Michay, n. 24, p. 24-33, $4^{\circ}$ trimestre 1983.

Revista Eletrônica da ANPHLAC, n.10, p. 83-125, jan./jun. 2011.

http://revista.anphlac.org.br/index.php/revista 
JARA, René. En las huellas de la esperanza. Temas: la narrativa chilena post-golpe. Araucaria de Chile, Madrid: Ediciones Michay, n. 39, p. 109-117, $3^{\circ}$ trimestre 1987. KOSICHEV, Leonard. Víctor Jara: tras las huellas del chileno en la Unión Soviética. Cronica. Araucaria de Chile, Madrid: Ediciones Michay, n. 27, p. 93-97, $3^{\circ}$ trimestre 1984.

LAGOS, Hugo. Explicar el Quilapayún. De los lectores. Araucaria de Chile, Madrid: Ediciones Michay, n. 18, p. 7-9, $2^{\circ}$ trimestre 1982.

LEON, Carlos. El muralismo chileno: comunicación y artes populares. Temas. Araucaria de Chile, Madrid: Ediciones Michay, n. 24, p. 109-118, 4 trimestre 1983. LITTIN, Miguel. Lo desmesurado espacio real del sueño americano. Temas. Araucaria de Chile, Madrid: Ediciones Michay, n. 29, p. 157-159, $1^{\circ}$ trimestre 1985. Conversación con Miguel Littin. Conversaciones. Araucaria de Chile, Madrid: Ediciones Michay, n. 21, p. 77-94, $1^{\circ}$ trimestre 1983. (Entrevista concedida a Isabel Parra).

LOPEZ CARMONA, Juan. Conversando en Paris con Tennyson Ferrada. Capítulos de la cultura chilena. Araucaria de Chile, Madrid: Ediciones Michay, n. 30, p. 154-161, $2^{\circ}$ trimestre 1985.

MALDAVSKY, José. Víctor Jara en la obra de un poeta marroquí. Varia Intención. Araucaria de Chile, Madrid: Ediciones Michay, n. 38, p. 221-213, $2^{\circ}$ trimestre 1987. MANSILLA, Luis Alberto. Exposición de exiliados. Notas en blanco y en negro. Araucaria de Chile, Madrid: Ediciones Michay, n. 8, p. 205-206, $4^{\circ}$ trimestre 1979. Claudio Arrau: la magia y el genio. Temas. Araucaria de Chile, Madrid: Ediciones Michay, n. 42, p. 97-115, $2^{\circ}$ trimestre 1988. Entrevista concedida a Êça Pereira da Silva. Santiago, 28 de setembro de 2007. MATTA, Roberto. Conversación con Matta. Temas. Araucaria de Chile, Madrid: Peralta Ediciones, n. 1, p. $79-1031^{\circ}$ trimestre 1978. (Entrevista concedida a Luis Gustavino e Guillermo Torres).

Segunda coversación con Matta. Conversaciones. Araucaria de Chile, Madrid: Ediciones Michay, n. 20, p. 37-61, $4^{\circ}$ trimestre 1980. (Entrevista concedida a Luis Bocaz, Carlos Orellana e Volodia Teitelboim).

MEDINA, Carlos. Las verdades brechitanas de Carlos Medina. Capítulos de la cultura chilena. Araucaria de Chile, Madrid: Ediciones Michay, n. 30, p. 146-153, $2^{\circ}$ trimestre 1985. (Entrevista concedida a Carlos Orellana). 
MILLAS, Orlando. Una digresión 1957-1991. Santiago: CESOC, 1996. v. IV, p. 173.

MORALES, José. El canto nuevo. Capítulos de la cultura chilena. Araucaria de Chile, Madrid: Peralta Ediciones, n. 2, p. 174-175, $2^{\circ}$ trimestre 1978.

MOUESCA, Jacqueline. Cine Chileno: los años de la dictadura. Temas. Araucaria de Chile, Madrid: Ediciones Michay, n. 41, p. 133-147, $1^{\circ}$ trimestre 1988.

MOUESCA, Jacqueline; ORELLANA, Carlos. El caso Raúl Ruiz. Temas. Araucaria de Chile, Madrid: Ediciones Michay, n. 23, p. 106-112, $3^{\circ}$ trimestre 1983.

NUÑEZ, Guillermo. Tomar la vida y los sueños de las manos. Capítulos de la cultura chilena. Araucaria de Chile, Madrid: Peralta Ediciones, n. 1, p. 141-147, $1^{\circ}$ trimestre 1978.

ORELLANA, Carlos. Quilapayún en cuatro tiempos. Cronica. Araucaria de Chile, Madrid: Ediciones Michay, n. 13, p. 193-195, $1^{\circ}$ trimestre 1981.

Araucaria festeja a Miguel Littin. Cronica. Araucaria de Chile, Madrid:

Ediciones Michay, n. 36, p. 199-203, 4 trimestre 1986.

Bitácora personal de una historia colectiva. Índice general de la Revista Araucaria de Chile, 1978-1989. Santiago: Ediciones del Litoral, 1994. p. 14.

Penúltimo informe. Memória de un exilio. Santiago:Sudamericana/Señales, 2002. p. 238.

. Entrevista concedida a Êça Pereira da Silva. Santiago, 01 de outubro de 2007. PARRA, Angel. La pasion del canto. Araucaria de Chile, Madrid: Ediciones Michay, n. 34, p. 153-168, $2^{\circ}$ trimestre 1986. (Entrevista concedida a Juan Armando Epple). Carta abierta a mi amigo Victor Jara. Cronica. Araucaria de Chile, Madrid: Ediciones Michay, n. 41, p. 46-47, $1^{\circ}$ trimestre 1988.

PICK, Zuzana M. Tradición y busqueda (1973-1983). Temas. Araucaria de Chile, Madrid: Ediciones Michay, n. 23, p. 95-106, $3^{\circ}$ trimestre 1983.

PINOCHET, Augusto. Patria y democracia. Santiago: Editorial Andres Bello, 1985.

PIZARRO ILLANES, Raul. El retorno de Balmés. Temas. Araucaria de Chile, Madrid: Ediciones Michay, n. 17, p. 145-148, $1^{\circ}$ trimestre 1982.

R. A. Cine Chileno: otros capítulos en exilio. Temas. Araucaria de Chile, Madrid: Ediciones Michay, n. 41, p. 148-150, 1 trimestre 1988.

RADRIGÁN, Juan. Radrigán: teatro de la dignidad y de la marginalidad. Capítulos de la cultura chilena. Araucaria de Chile, Madrid: Ediciones Michay, n. 31, p. 153-163, $3^{\circ}$ trimestre 1985. (Entrevista concedida a José Miguel Varas). 
RAMIREZ NECOCHEA, Hernán. Universidad Chilena: democracia y fascismo.

Capítulos de la cultura chilena. Araucaria de Chile, Madrid: Ediciones Michay, n. 3, p.101-116, $3^{\circ}$ trimestre 1978. (Entrevista a Luis Bocaz).

R.P. Las luces se apagan. Cronica. Araucaria de Chile, Madrid: Ediciones Michay, n. 2, p. $200-205,2^{\circ}$ trimestre 1978 .

ROJO, Grinor. El teatro chileno bajo el fascismo. Temas. Araucaria de Chile, Madrid: Ediciones Michay, n. 22, p. 123-136, 2 trimestre 1983.

RUIZ, Martín. Flores musicales del exilio chileno: Inti-Illimani cumple 20 años. Araucaria de Chile, Madrid: Ediciones Michay, n. 42, p. 83-94, $2^{\circ}$ trimestre 1988. (Entrevista con Inti-Illimani).

RUIZ, Raúl. No hacer más una película como si fuera la última. Capítulos de la cultura chilena. Araucaria de Chile, Madrid: Ediciones Michay, n. 11, p. 101-118, $3^{\circ}$ trimestre 1980. (Entrevista concedida a Luis Bocaz).

SANCHEZ, Cristián. El cine que se hace en Chile. Araucaria de Chile, Madrid:

Ediciones Michay, n. 28, p. 107-116, $4^{\circ}$ trimestre 1984. (Entrevista concedida a Oscar Zambrano).

SCHOPF. Federico. Fuera del lugar. Textos. Araucaria de Chile, Madrid: Ediciones Michay, n. 9, p. $145-154,1^{\circ}$ trimestre 1980.

SKÁRMETA, Antonio. Narrativa chilena después del golpe. Temas. Araucaria de Chile, Madrid: Ediciones Michay, n. 4, p. 149-167, 4 trimestre 1978.

SUBERCASEAUX, Bernardo. El canto nuevo 1973-1980. Cronica. Araucaria de Chile, Madrid: Ediciones Michay, n. 12, p. 201-206, $4^{\circ}$ trimestre 1980.

TEITELBOIM, Volodia. Un joven octogenario: Claudio Arrau. Araucaria de Chile, Madrid: Ediciones Michay, n. 22, p. 197-198, $2^{\circ}$ trimestre 1983. España en el corazón, Chile en el corazón. Araucaria de Chile, Madrid: Ediciones Michay, n. 40, p. 98-111, 4 trimestre 1987. Araucaria de Chile en Chile. Cronica. Araucaria de Chile, Madrid: Ediciones Michay, n. 42, p. 185-189, $2^{\circ}$ trimestre 1988.

. Entrevista concedida a Êça Pereira da Silva. Santiago, 04 de outubro de 2007. TORAL, Mario. Viaje de mi memoria. Temas. Araucaria de Chile, Madrid: Ediciones Michay, n. 18, p. 107-119, $2^{\circ}$ trimestre 1982.

URIBE ARCE, Armando. Funerales Q.e.p.n.d. Recuerdo de Gabriela Mistral. Temas. Araucaria de Chile, Madrid: Ediciones Michay, n. 32, p. 111-118, 4 trimestre 1985. 
URBINA, José Leandro. Coletanea narrativa chilena reciente. Textos. Araucaria de Chile, Madrid: Ediciones Michay, n. 12, p. 165-184, 4 trimestre 1980.

VARAS, José Miguel. El humor en la poesia y en la vida de Neruda. Araucaria de Chile, Madrid: Ediciones Michay, n. 26, p. 133-142, $2^{\circ}$ trimestre 1984.

VENTURELLI, José. Una vez que yo no esté... Temas. Araucaria de Chile, Madrid:

Ediciones Michay, n. 45, p. 157-161, $1^{\circ}$ trimestre 1989. (Entrevista concedida a Jaime Valedivieso).

VILLAGRA, Nelson. Víctor Jara: un adiós imposible. Aniversarios. Araucaria de Chile, Madrid: Ediciones Michay, n. 42, p. 29-38, $2^{\circ}$ trimestre 1988.

ZURITA, Raúl. Construyer una poesia tan grande cuanto la trajedia chilena.

Conversaciones. Araucaria de Chile, Madrid: Ediciones Michay, n. 36, p. 115-126, $4^{\circ}$ trimestre 1986. (Entrevista concedida a Carlos Orellana).

\section{Bibliografia}

AGGIO, Alberto. Democracia e socialismo: a experiência chilena. São Paulo: Annablume/UNESP, 2002.

ÁLVAREZ, Rolando; PINTO, Julio; VALDIVIA, Verónica. Su revolución contra nuestra revolución: izquierdas y derechas en el Chile de Pinochet (1973-1981). Santiago: LOM, 2006.

ARRATE, Jorge; ROJAS, Eduardo. Memoria de la izquierda chilena. Tomo II: 19702000. Santiago: Javier Vergara Editor, 2003.

CARRASCO, Eduardo. La revolución y las estrellas. In: LiteraMúsica, 2 ed. 2000. Disponível em: www.cancioneiros.com Acesso em 22 nov. 2002.

DALMAS, Carine. Brigadas muralistas e cartazes de propaganda da experiência. Chile (1970-1973). 2006. Dissertação (Mestrado em História) — Departamento de História da Faculdade de Filosofia Letras e Ciências Humanas, Universidade de São Paulo, São Paulo, 2006.

DE LUCA, Tânia Regina. História dos, nos e por meio dos periódicos. In: PINSKY, Carla Bassanezi (Org.). Fontes Históricas. São Paulo: Contexto, 2005.

GARRETÓN, M. A.; SOSNOWSKI, S.; SUBERCASEAUX, B. (Org.). Cultura, autoritarismo y redemocratización en Chile. Santiago: Fondo de Cultura Económica, 1993.

HUNEEUS, Carlos. El régimen de Pinochet. Santiago: Editorial Sudamericana, 2005.

Revista Eletrônica da ANPHLAC, n.10, p. 83-125, jan./jun. 2011. http://revista.anphlac.org.br/index.php/revista 
REBOLLEDO, Loreto. Memorias del desarraigo: testimonios de exilio y retorno de hombres y mujeres de Chile. Santiago: Catalonia, 2006.

OLIVEIRA, Ana Luiza Martins Camargo de. Revistas em Revista. Imprensa e prática culturais em tempos de república 1890-1922. 1997. Tese (Doutorado em História) Departamento de História da Faculdade de Filosofia, Letras e Ciências Humanas, Universidade de São Paulo, São Paulo, 1997.

OLMÓS, Ana Cecília. Revistas culturales de la transición: prácticas politicas y estrategias de intervención cultural - uma lectura comparada de Punto de Vista y Novo Estudo Cebrap. 2000. Tese (Doutorado em Literatura Hispanoamericana) Departamento de Letras da Faculdade de Filosofia Letras e Ciências Humanas, Universidade de São Paulo, São Paulo, 2000.

PATIÑO, Roxana; SCHWARTZ, Jorge. Introducción. Revista Iberoamericana. Revista literárias/ culturales latinoamericanas del siglo XX, n. 208-209, jul.-dic. 2004. SAID, Edward. Reflexões sobre o exílio e outros ensaios. São Paulo: Cia. das Letras, 2003.

SILVA, Êça Pereira da. La Nueva Canción Chilena: um encontro entre a arte e a política. 2003. Relatório (Iniciação Científica) - FAPESP, FFLCH, Universidade de São Paulo, São Paulo, 2003.

VARAS, Augusto. Los militares en el poder: régimen y gobierno militar en Chile 19731986. Santiago: Pehuén/ FLACSO, 1987. 